\title{
Sjögren's syndrome: studying the disease in mice
}

\author{
Nicolas Delaleu* , Cuong Q Nguyen², Ammon B Peck²,3,4 and Roland Jonsson ${ }^{1,5}$
}

\begin{abstract}
Sjögren's syndrome (SS), a systemic autoimmune disease, is characterized by inflammation of exocrine tissues accompanied by a significant loss of their secretory function. Clinical symptoms develop late and there are no diagnostic tests enabling early diagnosis of SS. Thus, particularly to study these covert stages, researchers turn to studying animal models where mice provide great freedom for genetic manipulation and testing the effect of experimental intervention. The present review summarizes current literature pertaining to both spontaneous and extrinsic-factor induced SS-like diseases in mouse models, discussing advantages and disadvantages related to the use of murine models in SS research.
\end{abstract}

\section{Introduction}

Assuming that studying a model organism will provide us with relevant information about the organism of our primary interest, investigation of nonhuman animals represents an important pillar in today's biomedical research. Over the past decades, the most popular experimental model to emerge is the common house mouse, irrespective of different living environments, the evolutionary distance and some well-recognized discrepancies in innate and adaptive immune responses between mice and men. Despite such concerns, researchers generally accept these limitations in order to circumnavigate technological and ethical issues related to research conducted in humans. Indeed, immunology has embraced the study of mice as a model organism and has accumulated tremendous insight into the intricacies of the human immune system and its involvement in both preventing and effecting disease.

In the present article, the murine models for Sjögren's syndrome (SS) are presented along the lines of spontaneous and extrinsic-factor induced models of SS-like

*Correspondence: nicolas.delaleu@gades.uib.no

'Broegelmann Research Laboratory, The Gade Institute, University of Bergen,

New Laboratory Building, 5th floor, \#5305, 5021 Bergen, Norway

Full list of author information is available at the end of the article disease and are discussed with special focus on disease phenotype and alterations induced in association with genetic modification and experimental intervention. We also highlight common biological themes reported in context with both the etiology and the underlying pathogenic mechanisms of experimental SS and address their potential relevance for SS in humans.

\section{Sjögren's syndrome: a summary}

SS is a chronic autoimmune disease, which mainly affects the exocrine glands. Nearly all patients complain of a persistent feeling of dry mouth (xerostomia) and dry eyes (keratoconjunctivitis sicca) [1,2]. These symptoms can be confirmed by multiple objective tests indicating significant functional impairment of the salivary and lacrimal glands. Histological evaluation of minor salivary glands obtained from patients with SS usually shows large and persistent focal infiltrates of mononuclear cells, often referred to as lymphocytic foci. These foci consist of mainly $\mathrm{T}$ cells, fewer $\mathrm{B}$ cells and smaller numbers of natural killer cells and dendritic cells. Often associated with such inflammation are acinar epithelial cell atrophy, progressive fibrosis and the presence of adipocytes in the salivary glands. Since approximately 60 to $80 \%$ of patients with SS produce anti-Ro antibodies and 40 to $60 \%$ produce anti-La autoantibodies [2], SS diagnosis also relies on the presence of these two biomarkers [3].

Affecting approximately 0.1 to $0.6 \%$ of the total population, SS is considered a relatively common rheumatic disease. In addition, SS is estimated to be 10 times more common in women compared with men. SS may extend from an autoimmune exocrinopathy to effect diverse extraglandular manifestations in the musculoskeletal, pulmonary, gastrointestinal, hepatobiliary, hematologic, vascular, dermatologic, renal and nervous systems. In contrast to systemic lupus erythematosus (SLE), where increased mortality has been reported as a consequence of the disease, the overall mortality in SS is comparable with the rate in the general population [4]. The risk of developing non-Hodgkin's lymphoma, however, is reported to be increased 16-fold in patients with SS compared with a control population [5]. Unfortunately, all therapies tested to date have proven ineffective in reversing the course of SS. Regrettably, relatively few studies in the field of rheumatology address SS specifically. 
With the possible exceptions of a few autoimmune diseases (for example, rheumatic heart disease), the etiology of most autoimmune diseases remains a mystery. The latter is also true for SS, despite multiple attempts to identify factors that might trigger the onset of a pathogenic immune response specifically directed against the exocrine glands. With a subset of SS patients exhibiting strong type 1 and type 2 interferon signatures [6,7], there is reason to believe that a viral agent is involved - but why some individuals are susceptible and others are not most probably resides in the individual's genetic background. An activated type 1 interferon system has also been described in other autoimmune diseases (for example, SLE) [8]. Much is known about the exogenous and endogenous inducers of type 1 interferons and the molecular pathways that may mediate a continuous interferon production involving Toll-like receptordependent amplification and propagation of the immune response [9]. Less is known, however, about and the functional role of specific gene variants in the regulation of the type 1 interferon system. Complicating this picture, unfortunately, is the fact that an important share of patients with SS suffers from secondary SS, defined as SS manifested in individuals diagnosed with other autoimmune diseases such as SLE, rheumatoid arthritis or scleroderma.

Another confounding factor in SS that has surfaced is the increasing recognition that the severity of secretory dysfunction does not necessarily correlate with the degree of leukocytic infiltration or the loss of acinar tissue. This raises the distinct possibility that immune process-related alterations within the glandular tissues, disturbing saliva production and/or secretion, are involved in the impairment of exocrine gland secretion observed in patients with SS [10,11].

The aim of the present review is to provide the reader with an overview and specific information about murine strains that have been proposed as models of SS. The review also highlights findings and hypotheses regarding the etiology and pathogenesis of SS that arose from research conducted in animal models $[12,13]$.

\section{Model organisms: a summary}

In principle, due to the common descent of all living organisms, discoveries made in one species might provide scientists with valuable information about another species. For this promise to be fulfilled, researchers depend on a critical level of conservation between the species studied and the species of primary interest. As stated earlier in the manuscript, the mouse is the organism of choice for the majority of immunologists and has also become an integral element of the bed-tobedside drug development strategy. As species, humans and mice diverged approximately 70 million years ago; and from an immunologist's point of view of special importance, they evolved in two different ecological niches. Nevertheless, the major paradigms about the working principles of the immune system appear to translate particularly well between the two species [14]. There is a need, however, for further delineation of species-specific differences in order to increase predictability of how findings from a murine strain may translate to a human population [14].

Direct comparison of the human and mouse genomes has confirmed the close relationship of these two mammalian species, as there are only about 300 genes that are unique to either humans or mice [15]. Because of differences in the development and lifespan between humans and mice, one may certainly argue that significant differences exist in the timing of gene expressions, but the basic workings of molecular and biological pathways have been shown to be similar, if not identical. One must remember, however, the aspects of very distinct differences in innate and adaptive immunity that exist between mice and men [14]. Nonetheless, one can only be impressed by how relevant information from mouse studies is to humans. To researchers, perhaps the most compelling feature in the context of research using animal models is the mouse lifespan and fertility. In addition, most societies grant scientists considerable liberties in testing new hypotheses in mice by allowing genetic manipulation and the strict control of an animal's living environment. As a consequence, resources related to research in mice became highly accessible - including thousands of inbred and genetically modified strains, detailed experimental protocols, elaborated researchrelated reagents and databases containing extensive data collections [16].

\section{Experimental research and Sjögren's syndrome}

Several aspects either directly related to the nature of SS or associated with current technical limitations underscore the necessity for research involving animal models. Prior to the onset of overt SS, physiological and structural changes are thought to take place in the exocrine glands, but due to the covert nature of the early stages of autoimmune diseases, studying these events in patients is virtually impossible. Similarly, collection of human specimens that represent a time course of the disease is difficult.

Ideally, a mouse model of SS mimics several clinical, histopathological and immunological features of the human disease combined with a high incidence of disease. In any cohort of SS patients, however, individuals are genetically diverse and the exhibited disease profiles are heterogeneous. There is thus significant reason to develop multiple murine strains, which manifest, to different extents, SS-like disease manifestations. This is 
also important as, obviously, each mouse only represents one genetic background. Unsuccessful clinical trials, based on seemingly promising results of treating autoimmune diseases in mice, might be due to the fact that the trial's design relied too heavily on a single mouse model; for example, nonobese diabetic (NOD) mice for the study of type 1 diabetes (T1D) [17].

Regarding mechanisms underlying the different aspects of the pathogenesis of SS, studying genetically altered strains allows the testing of more specific hypotheses with regard to, for example, a specific protein, cell type or functional pathway. Nevertheless, the overall functioning principles of a system can often not be predicted by studying the properties of its isolated parts as its state may strongly rely on the interaction of multiple components.

\section{Murine models of spontaneous disease}

In outbred populations of higher organisms such as rodents, cats, dogs and horses, the occurrence of inflammatory conditions reminiscent of autoimmune diseases in humans is not uncommon. Also comparable with the situation in humans is heterogeneity in terms of genetic backgrounds, disease activity and clinical manifestations displayed under outbred conditions. A potential explanation for this phenomenon might be related to a possible null correlation between some autoimmune diseases and reproductive success. Hence, model organisms that develop a SS-like disease spontaneously might well, as a group, represent the assumed multifactorial etiology and complex pathogenesis of SS in humans. As mostly inbred strains are used for research purposes, the conclusions drawn from an experimental study may translate well to a subpopulation of patients while being only partly valid or invalid for other groups of patients with SS.

The earliest murine models of SS identified were strains that develop SS-like disease manifestations spontaneously. A pertinent fact is that these models mimic in part as a group the complex genetics and diverse disease phenotypes found in patients with SS. The disease phenotypes of these strains are discussed below (Tables 1 and 2).

\section{$\mathrm{NZB}, \mathrm{NZW}$ and (NZB/NZW)F $\mathrm{F}_{1}$ mice}

In $(\mathrm{NZB} / \mathrm{NZW}) \mathrm{F}_{1}$ mice, histopathological manifestations of SS coincide with features reminiscent of SLE $[18,19]$. In NZW mice, exocrine gland inflammation is more pronounced in females compared with males, whereas this phenomenon is generally less apparent in NZB mice $[20,21]$.

Although other SS-related disease manifestations are not very pronounced in $(\mathrm{NZB} / \mathrm{NZW}) \mathrm{F}_{1}$ mice, a more recent study demonstrated that an unspecific inflammatory stimulus, evoked by Freund's incomplete adjuvant, can trigger a significant drop in salivary gland function already in an early phase of the disease, while this intervention protocol affected anti-Ro levels at a latter disease stage [22]. Thought to alter the sizes of T-cell subsets, administration of anti-CD25 monoclonal antibodies shortly after birth also exacerbates sialoadenitis and autoantibody production in this strain [23]. Lastly, Toll-like receptor 3 engagement through polyinosinic:polycytidylic acid has been studied in an attempt to recapitulate the effect of a dsRNA virus infection on the SS-like disease manifested in these mice [24]. As a result, inflammatory mediators downstream of Toll-like receptor 3 , such as type- 1 interferon, were transcribed and a concomitant transient loss in salivary gland secretory function was observed [24].

\section{MRL and MRL/Ipr mice}

In 1982 the MRL strain, at the time already established as a model of SLE, was reported to develop periductal lymphoid infiltrates in the salivary glands [25]. MRL/lpr mice differ from MRL mice with respect to a mutation involving the Fas gene [26]; however, negative selection in the thymus does not seem to be impaired in either strain [27]. In addition, irrespective of the lpr mutation in the Fas gene, MRL/lpr mice express a detectable amount of apoptosis-related FAS protein on lymphoid cells [28]. Nevertheless, defective apoptosis associated with the $l p r$ mutation results in increased susceptibility and severity of the disease, most probably through acceleration of the disease course [26,28].

Immunohistochemical analyses of the organs targeted by the inflammation show the presence of activated T cells $[29,30]$, whose importance was further confirmed in T-cell transfer experiments [31]. Inflammatory lesions in the salivary glands of MRL/lpr mice contain B cells producing IgA and IgM rheumatoid factor [32] and were, in addition, identified to be sites of IFN $\gamma$ production [30]. Of potential concern, despite female predominance and the rare occurrence of anti-Ro autoantibodies, the clinical hallmarks of SS - hyposalivation and keratoconjunctivitis sicca - are absent in this model.

\section{NFS/s/d mice}

The NFS/sld mouse provides a model in which aberrant immune responses against $\alpha$-fodrin are elicited [33]. A defect in salivary gland development leads to aberrant enzymatic proteolysis of the structural protein fodrin by caspase [33]. Indeed, some patients with SS produce antibodies specific to the $125 \mathrm{kDa}$ subunit of $\alpha$-fodrin [34]. However, the association between antibodies to $\alpha-$ fodrin and SS does not seem to be as strong as originally thought [35]. Thymectomy performed in NFS/sld mice 3 days after birth results in development of T-cell dominated infiltrates in the salivary and lacrimal glands, 
Table 1. Spontaneous models of Sjögren's syndrome

\begin{tabular}{|c|c|c|c|}
\hline $\begin{array}{l}\text { Strain/ } \\
\quad \text { modification }^{\mathrm{a}}\end{array}$ & SS-like disease manifestation $s^{b}$ & Remarks $^{b}$ & Reference \\
\hline$(\mathrm{NZB} / \mathrm{NZW}) \mathrm{F}_{1}$ & SG and LG infl. & SLE-like disease & [19] \\
\hline MRL & SG and LG infl. & SLE-like disease & [29] \\
\hline lpr & $\uparrow S G$ and LG infl. & Ipr exacerbates the MRL disease phenotype & [30] \\
\hline $\mathrm{NFS} / \mathrm{s} / \mathrm{d}$ & None & Aberrant proteolysis of a-fodrin & [33] \\
\hline $3 d-T x$ & SG and LG infl. & Inflammatory lesions in multiple organs & [34] \\
\hline IQI/Jic & SG and LG infl. & Inflammatory lesions in multiple organs & [37] \\
\hline NOD & SG and LG infl., $\downarrow S G$ and LG function & T1D, multiple immune system-related alterations & [12] \\
\hline$H 2^{b}$ & Similar to original NOD strain & NoT1D & [42] \\
\hline C57BL/6 & May develop SG infl. at an old age & Widely used recipient strain & \\
\hline NOD-Aec1Aec2 & SG and LG infl., $\downarrow S G$ and LG function & Increased applicability compared with NOD mice & [41] \\
\hline $112^{-1-}$ & SG and LG infl., $\downarrow$ SG function & Generalized lymphoproliferative disease & [91] \\
\hline$\| 2 R a^{-1-}$ & SG and LG infl., $\downarrow$ SG function & Generalized lymphoproliferative disease & [91] \\
\hline Foxp $3^{--}$ & None & More susceptible to SS-like disease & [94] \\
\hline 1/10 Tg & SG and LG infl., $\downarrow S G$ and LG function & $\uparrow$ apoptosis in the SG & [95] \\
\hline $1114 a \mathrm{Tg}$ & SG infl., $\downarrow$ SG function & High incidence of $\mathrm{CD}^{+}$lymphoma, nephritis & [101] \\
\hline BaffTg & SG and LG infl., $\downarrow S G$ function & MZ B-cell dominated infl., SLE-like disease & [106] \\
\hline $\operatorname{Tgf} \beta 1^{--}$ & SG and LG infl., $\downarrow$ SG function & Poor viability, mixed inflammatory cell response & [112] \\
\hline $\operatorname{Tg} f \beta 1 \mathrm{Tg}$ & $\downarrow$ SG function & Impaired SG architecture, SG tissue fibrosis & [113] \\
\hline Thbs $1^{-/-}$ & LG infl., anti-Ro and anti-La & Detailed assessment of the eye component & [116] \\
\hline $\mathrm{Ar}^{\prime-}$ & SG infl. & Estrogen-dependent disease & [119] \\
\hline RbAp48 Tg & SG and LG infl., $\downarrow$ SG function, anti-Ro and anti-La & Assessment of the inflammatory milieu in the SG & [122] \\
\hline $1 d 3^{-/-}$ & SG and LG infl., $\downarrow$ SG function, anti-Ro and anti-La & Exocrine gland dysfunction precedes SG and LG infl. & [125] \\
\hline Id $3^{-1-} ;$ LckCre & SG and LG infl., $\downarrow$ SG function, anti-Ro and anti-La & T-cell lineage specific deletion of Id3 & [126] \\
\hline$r 1 \Delta T / r 2 n$ & SG and LG infl., anti-Ro & $\downarrow T_{\text {regs' }}$ inflammatory lesions in multiple organs & [130] \\
\hline IKBa $a^{M / M}$ & SG and LG infl., anti-Ro and anti-La & Defective feedback regulation of NF-KB & [133] \\
\hline C57BL/10 & May develop SG infl. at an old age & C57BL/6 and C57BL/10 diverged prior to 1937 & \\
\hline NOD-Nss $1 / / d d 5$ & SG infl. & SG function has not been assessed & [82] \\
\hline SJL & SG and LG infl., anti-Ro and anti-La & Susceptible to multiple autoimmune diseases & [98] \\
\hline $1 / 12 \mathrm{Tg}$ & $\uparrow S G$ and LG infl., $\downarrow S G$ function, $\uparrow$ anti-Ro and anti-La & IL-12 exacerbates the SJL disease phenotype & [98] \\
\hline $\mathrm{BALB} / \mathrm{C}$ & None & Often used as control strain & \\
\hline $\mathrm{Act1}^{-1-}$ & SG and LG infl., anti-Ro and anti-La & MZ B-cell dominated infl., SLE-like disease & [115] \\
\hline
\end{tabular}

Selection of murine strains in which Sjögren's syndrome (SS)-like disease manifestations develop spontaneously. $\uparrow$, increased; $\downarrow$, decreased; Ar, aromatase; 3d-Tz, 3 days after birth thymectomy; infl, inflammation; LG, lacrimal gland; $M Z$, marginal zone; NOD, nonobese diabetic mice; SG, salivary gland; SLE, systemic lupus erythematosus; T1D, type 1 diabetes; $\mathrm{Tg}$, transgenic; $\mathrm{T}_{\text {reg' }}$ regulatory $\mathrm{T}$ cell. ${ }^{\mathrm{a}}$ Specific modification of the original strain. ${ }^{\mathrm{b} F o r}$ modified strains, listings refer to relative changes compared with the original, not indented, strain listed above.

and - secondary to the SS-like disease - the NFS/sld mice undergoing thymectomy 3 days after birth also tend to develop inflammatory lesions in other organs [36].

\section{IQI/Jic mice}

The IQI/Jic strain was developed from the same stock that gave rise to the NOD mouse. Selection, however, was for mice that exhibited a SS-like disease comparable with NOD mice but in the absence of T1D. IQI/Jic mice develop focal inflammation in the salivary and lacrimal glands, accompanied by parenchymal destruction [37]. Sialoadenitis progresses over time and becomes more prominent in females compared with males. IQI/Jic mice also develop inflammatory lesions in several other organs, including the lung, pancreas and kidneys [38].
Interestingly, kallikrein-13 has recently been suggested to play a role in the etiology of the SS-like disease manifested in IQI/Jic mice [39]. Kallikreins, together with other proteases, were found to be part of the salivary proteome characteristic for patients with SS [40].

\section{Nonobese diabetic mice and related strains}

The NOD strain descends from a cataract-prone strain of outbred Jcl/ICR mice and is today the most extensively characterized model of SS and T1D. Although some genetic loci related to diabetes (idd $d^{s}$ loci) contribute to the inflammatory changes in the exocrine glands, it seems that diabetes and SS develop independently of each other [41-43]. T1D in NOD mice is restricted to the expression of the class II major histocompatibility 
Table 2. Alterations in disease phenotype observed in association with genetic modification and experimental intervention

\begin{tabular}{|c|c|c|c|}
\hline $\begin{array}{l}\text { Strain/ } \\
\text { modification/ } \\
\text { intervention }\end{array}$ & SS-like phenotype ${ }^{a}$ & Remarks $^{\mathrm{a}}$ & Reference \\
\hline$(\mathrm{NZB} / \mathrm{NZW}) \mathrm{F}_{1}$ & SG and LG infl. & SLE-like disease & [19] \\
\hline IFA & $\uparrow$ SG infl., $\downarrow$ SG function, anti-Ro & $\uparrow D C$ numbers early in the disease process & [22] \\
\hline Anti-CD25 & 个SG infl., anti-Ro & $\uparrow$ ANA & [23] \\
\hline Poly(l:C) & $\downarrow$ SG function (transient) & Role of TLR3 engagement & [24] \\
\hline NOD & SG and LG infl., $\downarrow S G$ and LG function & T1D, multiple immune system-related alterations & [12] \\
\hline scid & No SG infl., $\uparrow$ SG function & Abnormal salivary gland physiology remains & [60] \\
\hline $\lg \mu^{\text {null }}$ & $\uparrow S G$ function & Insulitis but no progression to overt T1D & [64] \\
\hline $114^{-/-}$ & $\uparrow S G$ function & Absence of anti-M3R IgG & [77] \\
\hline Ifny $\gamma^{-1-}$ & No SG infl., $\uparrow$ SG function, $\uparrow$ LG infl. & Retained LG infl. & [78] \\
\hline Ifny $R^{-1-}$ & No SG infl., $\uparrow$ SG function, $\uparrow$ LG infl. & Retained LG infl. & [78] \\
\hline Tnfrl-FclgG $\mathrm{Tg}_{3}$ & $\downarrow S G$ and LG infl. & Insulitis but no progression to overt T1D & [75] \\
\hline $1 \mathrm{ca} 69^{-1}$ & $\downarrow S G$ and LG infl. & Unchanged incidence rate of T1D & [61] \\
\hline Aire ${ }^{-/-}$ & $\uparrow L G$ infl., $\downarrow L G$ function & Role of OBP1a and central tolerance & [63] \\
\hline NZW-Ssial3 & $\downarrow$ SG infl., SG function unchanged & Unchanged insulitis score & [55] \\
\hline$E 2 f^{-1-}$ & $\uparrow$ SG infl., $\downarrow$ SG function & $\uparrow T 1 D, \downarrow T_{\text {reas }}$ & [58] \\
\hline Hsp60 & $\downarrow$ SG infl., $\uparrow$ SG function & Biomarkers in saliva predict treatment success & [57] \\
\hline Hsp60 amino acids 437 to 460 & $\downarrow$ SG infl., $\uparrow$ SG function & Biomarkers in saliva indicate SG function & [57] \\
\hline LTRR-Ig & Arrested progression of SG infl. & Changes in cellular composition of SG infl. & [48] \\
\hline Anti-VCAM1 & $\downarrow L G$ infl. & LG function, SG infl. and SG function not assessed & [76] \\
\hline Anti-a-integrin & $\downarrow L G$ infl. & LG function, SG infl. and SG function not assessed & [76] \\
\hline Anti-PNAd & $\downarrow L G$ infl. & LG function, SG infl. and SG function not assessed & [76] \\
\hline Anti-L-selectin & $\downarrow L G$ infl. & LG function, SG infl. and SG function not assessed & [76] \\
\hline Anti-LFA1 & $\downarrow L G$ infl. & LG function, SG infl. and SG function not assessed & [76] \\
\hline 1110 & $\downarrow$ SG infl., $\uparrow$ SG function & Retrograde gene delivery through SG ducts & [96] \\
\hline Tnfri-lg & $\downarrow$ SG function & Retrograde gene delivery through SG ducts & [74] \\
\hline $\mathrm{NOD}-\mathrm{H} 2^{b}$ & SG and LG infl., $\downarrow S G$ and LG function & NoT1D & [42] \\
\hline $114^{-/-}$ & $\uparrow S G$ function & Absence of anti-M3R IgG & [65] \\
\hline C.Stat6 $6^{--}$ & $\uparrow S G$ function & Absence of anti-M3R $\lg G_{1}$ & [66] \\
\hline NOD-scid & No SG infl., normal SG function & Abnormal salivary gland physiology remains & [60] \\
\hline $\mid f n \gamma^{-/}$ & No SG and LG infl., $\uparrow$ SG function & Improved salivary gland physiology & [78] \\
\hline$E 2 f 1^{-1-}$ & No SG infl., retained $\downarrow$ SG function & Effect of E2F1 deficiency on SG development & [59] \\
\hline C57BL/6.NOD-Aec1Aec2 & SG and LG infl. $\downarrow S G$ and LG function & Increased applicability compared with NOD mice & [41] \\
\hline $\mathrm{C}^{--}$ & No SG and LG infl., $\uparrow$ SG function & Assessing the role of $\mathrm{C} 3$ & [88] \\
\hline$\| 17 r: F C$ & $\downarrow$ SG infl., $\uparrow$ SG function & Retrograde gene delivery through SG ducts & [81] \\
\hline C57BL/6 & May develop SG infl. at an old age & Widely used recipient strain & \\
\hline $1117 a$ & SG infl., $\downarrow$ SG function & Retrograde gene delivery through SG ducts & [80] \\
\hline C57BL/6-I/14a Tg & SG infl., $\downarrow$ SG function & High incidence of $\mathrm{CD}^{+}$lymphoma, nephritis & [101] \\
\hline $\mathrm{Lta}^{-/-}$ & $\downarrow$ SG infl., $\uparrow$ SG function & LTa-dependent disease phenotype & [104] \\
\hline C57BL/6-ld3 $3^{-1-}$ & SG and LG infl., $\downarrow$ SG function, anti-Ro and La & Exocrine gland dysfunction precedes SG and LG infl. & [125] \\
\hline Anti-CD20 & $\downarrow S G$ and LG infl., $\uparrow$ SG function & Depletion of B cells & [127] \\
\hline C57BL/6-BaffTg & SG and LG infl., $\downarrow S G$ function & MZ B-cell dominated infl., SLE-like disease & [106] \\
\hline$L t \beta^{--}$ & $\downarrow$ SG infl., $\uparrow$ SG function & MZ B-cell dependence of the SS-like disease & [107] \\
\hline $\operatorname{Tnfa}^{-\alpha}$ & Unchanged & Increased incidence of B-cell lymphoma & [110] \\
\hline $\mathrm{BALB} / \mathrm{C}-\mathrm{Act} 7^{-/-}$ & SG and LG infl., anti-Ro and anti-La & MZ B-cell dominated infl., SLE-like disease & [115] \\
\hline $\mathrm{CD} 40^{-/}$ & SG and LG infl. unchanged & Absence of anti-Ro and anti-La & [115] \\
\hline
\end{tabular}

Selection of genetic modifications and specific intervention, which gave insight into the mechanisms underlying either the etiology or the pathogenesis of Sjögren's syndrome (SS)-like disease in the original strain. $\uparrow$, increased; $\downarrow$, decreased; AIRE, autoimmune regulator; ANA, antinuclear antibodies; DC, dendritic cells; E2F1, E2F transcription factor 1; HSP, heat shock protein; IFA, Freund's incomplete adjuvant; infl., inflammation; LFA, leukocyte function-associated antigen; LG, lacrimal gland; LT, lymphotoxin; M3R, muscarinic acetylcholine type-3 receptor; MZ, marginal zone; NOD, nonobese diabetic mice; OBP1a, odorant binding protein 1a; PNAd, peripheral node addressin; poly $(I: C)$, polyinosinic:polycytidylic acid; scid, severe combined immunodeficiency; SG, salivary gland; SLE, systemic lupus erythematosus; STAT, signal transducer and activator of transcription; T1D, type 1 diabetes; Tg, transgenic; TLR, Toll-like receptor; $T$, regulatory T cell; VCAM, vascular cell adhesion molecule. ${ }^{2}$ For all modified strains and interventions, listings refer to relative changes compared with the original, not indented, strain listed above. 
complex (MHC) haplotype $\mathrm{H}^{g^{7}} \quad[44]$. Whereas NOD.B10-H $H 2^{b}$ mice are resistant to the onset of overt T1D, they still exhibit the main disease manifestations of SS [42]. The exact extent and cellular composition of the glandular inflammation in NOD.B10-H2 $H 2^{b}$ mice, however, remains to be defined.

NOD mice in which the original MHC $\mathrm{H} 2^{g 7}$ haplotype was replaced with an $\mathrm{H}_{2}^{q}$ or $\mathrm{H}^{p}$ haplotype were also investigated. In summary, while the difference in $\mathrm{H} 2$ haplotype did not seem to affect the frequency of sialoadenitis, the disease severity varied among these strains [43]. Interestingly, introduction of the $\mathrm{H}^{q}$ haplotype directed the autoimmune response towards the production of SLE-associated autoantibodies and a higher incidence of kidney pathology [43].

Autoimmune manifestations in NOD mice represent a complex disease involving genetics, sensitivity to exogenous factors and defects in central and peripheral tolerance [44]. These factors have also been reported to contribute to the susceptibility of the strain to develop autoimmune thyroiditis [45], SLE [46], myasthenia gravis [47] and autoimmune encephalomyelitis [44] subsequent to specific intervention.

In NOD mice, focal inflammation in the submandibular salivary glands and the lacrimal glands develops from approximately 8 weeks of age onwards. The foci appear comparable in structure and cellular composition with infiltrates found in human salivary glands (Figure 1) $[48,49]$, and gender-related differences in the degree of exocrine gland inflammation have also been reported in this strain [50]. As in patients with SS, in NOD mice the relationship between histopathological changes and hyposalivation is not always obvious - which indicates a certain autonomy of the autoimmune manifestations of SS (Figure 2) [51]. Exocrine gland inflammation in NOD mice appears to precede the onset of hyposalivation by a considerable amount of time [52]. Interestingly, transition to an overt disease does not necessarily need to be associated with a significantly higher degree of glandular inflammation [52], but hyposalivation and reduction in lacrimation were rather correlated with the occurrence of B-cell response-related gene transcripts in the exocrine glands $[53,54]$.

Supporting the notion of a certain independence between degree of inflammation and glandular hypofunction, introduction of an NZW-derived interval of chromosome 7 (annotated Ssial3) into NOD mice moderated sialoadenitis without ameliorating salivary gland function [55]. Analyses of dozens of inflammatory mediators in serum and saliva obtained from NOD mice, furthermore, only revealed a minimal number of biomarkers correlating with several SS-related disease manifestations in an association network [56]. In addition, successful prevention of hyposalivation - through administration of $60 \mathrm{kDa}$ heat-shock protein and of 60 kDA heat-shock protein-derived peptide amino acids 437 to 460 - did not coincide with a corresponding decrease in salivary gland inflammation [57]. In contrast, biomarker signatures generated from saliva, indicating qualitative changes in salivary gland inflammation, predicted treatment outcome and salivary gland function with high accuracy [57]. Several lines of evidence indicate that as T1D progresses from early insulitis to overt diabetes there is a loss of immune cell subsets, such as regulatory $\mathrm{T}$ cells $\left(\mathrm{T}_{\text {regs }}\right)$ and invariant natural killer $\mathrm{T}$ cells within the islets [17]. Unfortunately, little is still known about the role of these cell subsets in the progression of SS. Nevertheless, NOD mice deficient for E2F transcription factor $1-$ a regulator of T-cell proliferation, differentiation, and apoptosis - have a pronounced decrease in $\mathrm{CD} 4^{+} \mathrm{CD} 25^{+} \mathrm{T}_{\text {regs }}$ and seem to be highly predisposed not only to T1D but also to SS [58]. In order to investigate the effects of E2F transcription factor 1 deficiency prior to the involvement of the adaptive immune system, the SS disease profile was later assessed in NOD-E2 $\mathrm{fl}^{-/-}$mice, which, in addition, carried the severe combined immunodeficiency (scid) mutation. Interestingly, this strain's saliva secretion capacity was found impaired [59] irrespective of the severe deficiencies in adaptive immunity and the absence of exocrine gland inflammation reminiscent of SS mediated by the scid mutation [60].

Another possible connection between SS and T1D in NOD mice might involve common autoantigens. Disruption of the islet-cell autoantigen $69 \mathrm{kDa}$ gene in NOD mice, a self-antigen associated with diabetes that is expressed not only in the pancreas but also in the exocrine glands, reduced SS-related histopathology and glandular hypofunction [61]. A study investigating a large cohort of patients with SS could not, however, confirm a role or true frequency of islet-cell autoantigen $69 \mathrm{kDa}$ autoimmunity in patients with SS [62]. Studying the role of autoimmune regulator deficiency and central tolerance in the context of SS in NOD and Balb/c mice identified odorant binding protein $1 \mathrm{a}$ as a potential autoantigen involved in the etiology of autoimmune-mediated lacrimal gland pathogenesis [63].

To determine whether B cells contribute to the SS-like disease, experiments were carried out in NOD-Ig $\mu^{\text {null }}$ mice, which lack mature B cells [64]. The results indicate that in SS, in contrast to T1D, B cells do not significantly participate in the initiation phase of the disease $[44,64]$. However, B-cell activity appears to be critical in the transition to an overt disease stage in these mice, since, despite the presence of $\mathrm{T}$ cells in the salivary glands, NOD-Ig $\mu^{\text {null }}$ mice fail to develop hyposalivation [64]. Subsequent studies also documented the concomitant lack of hyposalivation and anti-muscarinic acetylcholine 


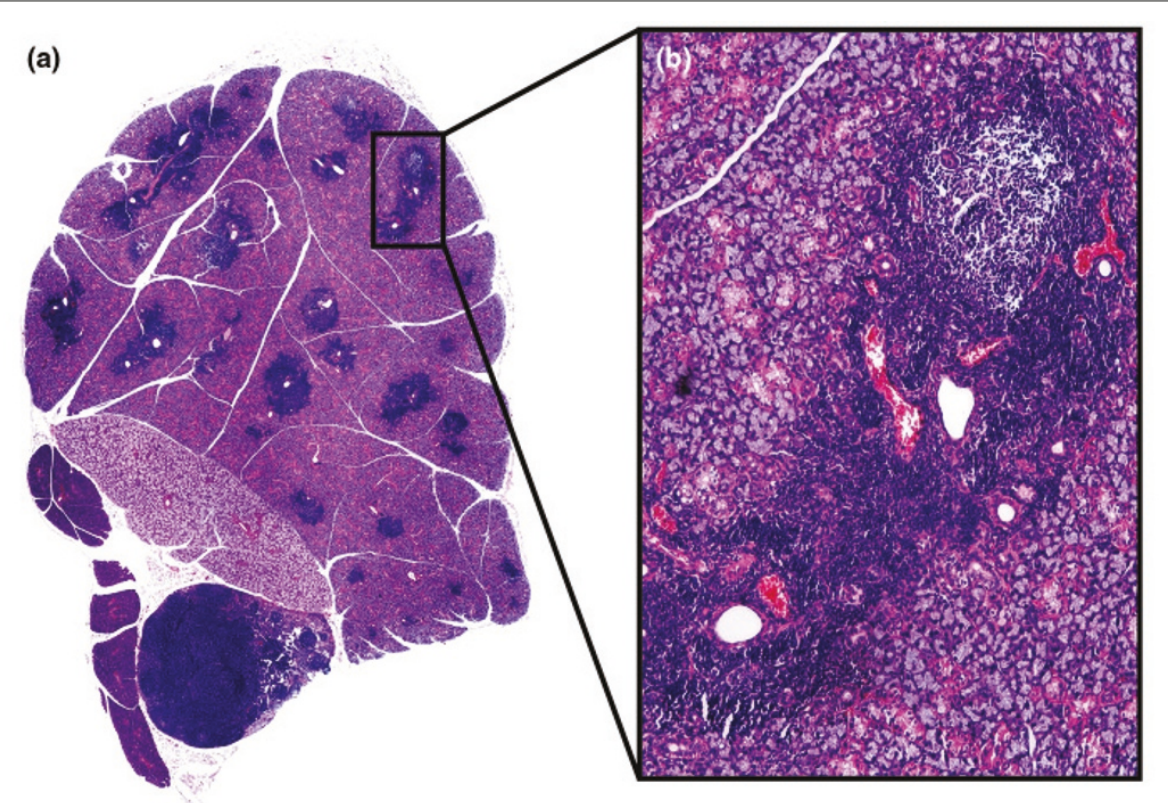

Figure 1. Salivary gland histopathology. Focal mononuclear cell infiltration of the salivary gland characteristic for Sjögren's syndrome.

(a) Hematoxylin and eosin stained section of a submandibular gland, a sublingual gland and parts of the parotid salivary gland with a lymph node. (b) Magnification of a focal mononuclear cell infiltrate. The specimen was obtained from a 21-week-old nonobese diabetic mouse. Figure adapted from [51].

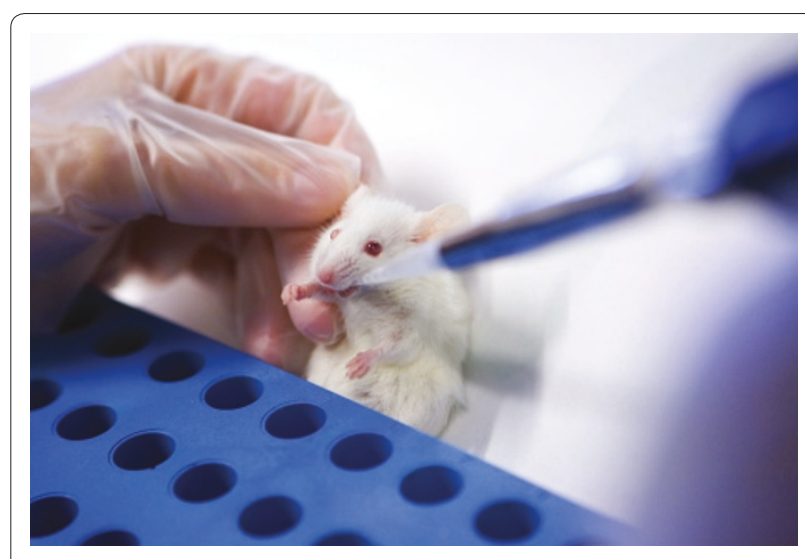

Figure 2. Assessment of salivary gland secretion capacity. Saliva collection and measurement of the salivary flow rate in an anesthetized nonobese diabetic mouse subsequent to the intraperitoneal injection of pilocarpine. Figure reproduced with kind permission from Springer Science \& Business Media [13], photograph by Nicolas Delaleu.

type-3 receptor (M3R) autoantibodies of the $\mathrm{IgG}_{1}$ isotype in IL-4-deficient and signal transducer and activator of transcription 6-deficient NOD strains $[65,66]$. In connection with possible non-inflammatory mechanisms underlying the onset of hyposalivation, an altered aquaporin 5 distribution - similar to the patterns observed in human specimens - has also been described in exocrine glands obtained from NOD mice $[67,68]$.
Protection from T1D in NOD mice has been associated with a shift from a Th1 to a Th2 cytokine expression profile in autoreactive $\mathrm{T}$ cells [17]. Results obtained in subsequent studies, however, indicated that compartmentalization into disease-promoting Th1 and protective Th2 cytokines cannot be applied to the overall pathogenesis manifested in NOD mice [69]. The emergence of novel immune-cell subsets such as $\mathrm{T}_{\text {regs }}$ and Th17 cells further questions the validity of such models [70,71].

Cytokine expression in the exocrine glands obtained from NOD mice has been analyzed [72,73]. In a later study, taking advantage of recent technological developments, more comprehensive sets of inflammatory mediators were analyzed in serum and saliva obtained from NOD mice [56]. Furthermore, blocking of either lymphotoxin $\beta R$ or TNFR1 signaling has given insight into the implication of these two TNF family members in the development of the SS-like disease in NOD mice $[48,74]$. Whereas lymphotoxin $\beta R$ signaling appears to affect the degree and cellular composition of salivary gland inflammation [48], inhibition of TNFR1 engagement has been suggested to exacerbate the manifestation of hyposalivation [74]. In an earlier study, however, transgenic overexpression of TNFR1 inhibited exocrine gland inflammation [75]. Investigation of antibodymediated inhibition of lymphocyte migration as a potential treatment strategy demonstrated that $\alpha_{4} \beta_{1}$-integrin, leukocyte selectin and leukocyte function-associated 
antigen 1 expression on lymphocytes and that vascular cell adhesion molecule 1 expression and peripheral node addressin on endothelial cells are required for lymphocyte homing to the lacrimal gland of NOD mice [76].

The functional roles of Th1 and Th2 cytokines in the pathogenesis of SS have been assessed in some detail by comparing a set of gene knockout mice: NOD-Il4 ${ }^{-/-}$[77], NOD.B10-H2 $2^{b}-I l 4^{-/-}$[65], NOD.B10-H2 ${ }^{b}$-C.Stat6 ${ }^{-/}$[66], NOD-Ifn $\gamma^{-/}$and NOD-Ifnyr ${ }^{-/}$[78] mice. Il4 ${ }^{-/-}$NOD mice and $\mathrm{Stat6}^{-/-}$NOD mice retain salivary secretion rates similar to $\mathrm{Balb} / \mathrm{c}$ mice despite the fact that they continued to present with exocrine gland inflammation $[65,66]$. NOD-Ifn $\gamma^{-/}$mice and NOD-Ifnyr ${ }^{-/-}$mice were found to develop neither sialoadenitis or hyposalivation nor to present the signs of delayed salivary gland organogenesis present in the salivary gland of the parental NOD strain $[60,78]$. Of note, the mononuclear cell infiltrates within the lacrimal glands persisted in these two latter strains [78]. Results regarding the more recently described Th17-cell subset suggest that the Th17/IL-23 system is activated in a NOD-derived strain during the overt state of the disease [79]. Interestingly, local IL-17A expression as a result of adenovirus vector-associated Il17a delivery to the salivary gland of SS nonsusceptible C57BL/6 mice recapitulated to a large extent the SS-like disease phenotype described in the NOD strain [80]. Subsequent investigation of IL-17 as a therapeutic target at different disease stages showed that gene therapyinduced inhibition of IL-17, through expression of its receptor in the salivary gland, had the capacity to significantly reduce several important features of the SS-like disease, including salivary gland inflammation and severity of hyposalivation [81].

To investigate the importance of specific gene regions with regard to SS-like disease manifestations, NODspecific genetic loci were introduced into either a C57BL/6 background [41] or a C57BL/10 background [82]. For both strains, gene expression of the salivary gland tissues was compared with their respective parental strain $[54,82,83]$. Unfortunately, the C57BL/10-based model termed B10.Q-Nss1/Idd5 has not been assessed for salivary gland hypofunction [82].

The principal aim for the development of the C57BL/6based model named C57BL/6.NOD-Aec1Aec2 was primarily to circumnavigate three problems associated with its parental NOD strain: the known impact of overt T1D on the physiological process of saliva and tear secretion as well as the possible interference of T1D, overt or asymptomatic, with biological readouts obtained from the NOD strain; the fact that there is no appropriate comparative nondiseased control strain for NOD mice; and the presence of a multitude of immune systemassociated defects in the NOD strain [44].
The genes within the genetic regions designated Aec1 (Idd5 on chromosome 1) and Aec2 (Idd3 on chromosome 3) appear sufficient for the manifestation of a SS-like disease phenotype comparable with the one manifested in NOD mice [41]. First steps towards fine-mapping of $A e c 2$ were undertaken with the purpose of identifying candidate genes potentially regulating SS-associated autoimmunity [84]. Nevertheless, although considered nonsusceptible to the development of a SS-like disease, the genomes of $\mathrm{C} 57 \mathrm{BL} / 6 \mathrm{~J}$ or $\mathrm{C} 57 \mathrm{BL} / 10$ might still contribute to the congenic strain's disease phenotype by enhancing the primary effects introduced by the congenic regions [85]. Such phenomena render it more difficult to discriminate between disease-causing and diseasepromoting gene segments. In addition, the two recipient strains may develop spontaneous sialoadenitis as they age $[82,86]$. The improved applicability of the C57BL/6.NOD$A e c 1 A e c 2$ strain compared with the original NOD mice, however, facilitated the study of proteases in the initiation phase of the disease [87], a more distinct delineation of the salivary and lacrimal gland transcriptome prior to and during the onset of the SS-like disease [53,54], as well as assessment of a potential role of complement 3 in SS [88].

\section{Gene knockout and transgenic models}

Genetic modifications have been shown to trigger different aspects of the SS-like disease in murine models. The fact that silencing or overexpression of a single gene can result in a disease profile reminiscent of SS points to pathways downstream of this particular gene. These pathways are commonly associated with either regulating the immune response, governing developmental processes or contributing to exocrine gland homeostasis. A discussion of gene knockout and transgenic models of SS follows (Tables 1 to 3 ).

\section{IL-2-deficient, IL-2Ra-deficient and forkhead box P3-deficient mice}

The first indication that IL-2 activities are diminished in NOD mice was first reported in 1993 [89] and was later found to be associated with Idd3 [90]. Today, IL-2 is recognized as a critical factor in promoting differentiation and activation of $\mathrm{T}_{\text {regs }}$. Concordantly, inhibition of circulating IL-2 led to aggravation of diverse autoimmune manifestations in NOD mice [45], and both IL-2-deficient and IL-2R $\alpha$-deficient C57BL/6 mice present with exocrine gland inflammation and hyposalivation $[91,92]$. The SS-like disease in the two strains develops, however, secondary to a generalized lymphoproliferative disease characterized by autoimmune hemolytic anemia and inflammatory bowel disease [93]. Nevertheless, data collected on IL-2 in a SS-related context indicate that in conditions with decreased regulatory cell populations the salivary glands are prone to exhibit autoimmune 
Table 3. Extrinsic factor-induced models of Sjögren's syndrome

\begin{tabular}{lllll}
\hline Strain & Extrinsic factor & SS-like disease manifestations & Remarks & Reference \\
\hline BALB/C & Ro amino acids 480 to 494 & SG infl., $\downarrow$ SG function, anti-Ro and anti-La & Low disease penetrance rate & [136] \\
& Ro amino acids 274 to 290 & SG infl., $\downarrow$ SG function, anti-Ro and anti-La & Low disease penetrance rate & [136] \\
C57BL/6-Rag 1-- & Six peptides from M3R & SG and LG infl., $\downarrow$ SG function & Splenocytes from vaccinated M3r $r^{-}$mice & {$[140]$} \\
PL/J & CAll & SG infl. & Inflammatory lesions in multiple organs & {$[142]$} \\
C57BL/6-gld//gld & MCMV & SG infl., anti-Ro and anti-La & Incomplete clearance of the MCMV & {$[144]$} \\
\hline
\end{tabular}

Selection of murine strains in which Sjögren's syndrome (SS)-like disease manifestations develop after the administration of specific extrinsic factors. $\uparrow$, increased;

$\downarrow$, decreased; CAll, carbonic anhydrase II; infl., inflammation; LG, lacrimal gland; M3R, muscarinic acetylcholine type-3 receptor; MCMV, murine cytomegalovirus; SG, salivary gland.

manifestations. Inconsistently, however, mice that carry the forkhead box P3 (Foxp3)sf mutant gene and are therefore deficient for Foxp $3^{+}$-positive $\mathrm{T}_{\text {regs }}$ remain free of glandular inflammation as long as they are not exposed to lipopolysaccharide [94]. Nonetheless, cells isolated from their lymph nodes had the capacity to induce sialoadenitis in immunocompromised, recombination activating gene-1-deficient recipient mice [94].

\section{IL-10 transgenic mice}

Overexpression of IL-10 in C57BL/6J mice provokes progressive histopathology and hyposalivation suggestive of SS [95]. Il10 transfer into NOD mice, however, partially suppressed the appearance of SS-like features [96] indicating a dual role of IL-10 in SS, most probably dependent on temporal or site-specific expression patterns of IL-10.

\section{IL-12 transgenic mice}

The influence of IL-12 is considerably clearer. Both CBA [97] and SJL [98] mice transgenic for Il12 exhibit focal inflammation within their exocrine glands, with the latter strain showing an additional array of SS-related manifestations, including hyposalivation and modest increases in autoantibody levels upon aging [98]. In this context, it should be noted that SJL mice are generally susceptible to pathogenic autoimmunity and are also highly prone to develop B-cell lymphoma [99]. In an earlier study, concurrent intraperitoneal injection of IL-12 and IL-18 triggered severe atrophy of the salivary and lacrimal glands of various strains [100]. These degenerative changes in glandular tissues, however, occurred without lymphocytes concomitantly infiltrating the affected glands [100].

\section{IL-14a transgenic mice}

By promoting expansion and activation of specific B-cell subsets, Il14 $\alpha$ transgenic C57BL/6 mice present with hypergammaglobulinemia by 3 months of age, with exocrine gland inflammation by 6 months of age [101,102]. In addition, this strain develops immune-complexmediated nephritis, as well as exhibiting a high incidence of $\mathrm{CD}^{+}$B-cell lymphoma [101]. Strengthening the relevance of this model, a recent study demonstrated a strong dependence of the SS-like disease manifestations on local expression of lymphotoxin $\alpha$, a molecule crucial for the maintenance of organized lymphoid microenvironments in target tissues of autoimmune diseases [103]. Il14 $\alpha$ transgenic mice deficient for lymphotoxin $\alpha$ retained normal saliva secretion and presented no signs of salivary gland inflammation or secondary lymphoma development [104]. This strain also no longer presented the disproportionally large $\mathrm{CD}^{+} \mathrm{B}$-cell compartment, characteristic for mice overexpressing $I l 14 \alpha$ [104].

\section{B-cell-activating factor transgenic mice}

B-cell-activating factor (BAFF), also known as B-lymphocyte stimulator, has emerged as a critical regulator of $\mathrm{B}$ cell survival and maturation, demonstrating the need for an obligate survival signal for both maturing and fully differentiated B cells [105]. Excess BAFF-mediated survival signals are thought to aid autoreactive B cells to escape apoptosis, to expand and, subsequently, to exert their potentially pathogenic activities [105].

BAFF received considerable attention following development of Baff transgenic strains, of which one was shown to develop features reminiscent of SS, including lymphoid infiltrates in the salivary and lacrimal glands and hyposalivation [106]. The manifestation of the SSlike disease thereby critically depends on B cells with a marginal zone B-cell like phenotype, which are the dominant lymphocyte population infiltrating the salivary glands from this strain [107]. Despite the high numbers of B cells, anti-Ro antibodies or anti-La antibodies were not detected. Strains overexpressing BAFF also develop severe autoimmune manifestations traditionally associated with SLE, including circulating immune complexes, anti-DNA antibodies and immunoglobulin deposition in the kidneys [108,109]. Disruption of Tnfo in Baff transgenic mice furthermore revealed a critical role of the anti-tumor activity of TNF $\alpha$ in this strain [110].

\section{Transforming growth factor beta 1 transgenic and deficient mice}

Transforming growth factor (TGF) beta1 is a multifunctional molecule that has effects on many developmental, physiological and immunological processes. Animals 
carrying a mutated $\operatorname{Tg} f \beta 1$ allele present a syndrome marked by mixed inflammatory cell responses and tissue necrosis, in many cases leading to organ failure and death [111]. In surviving mice, the syndrome includes inflammation of the exocrine glands in a large share of the animals that can, however, be prevented by systemic injections of synthetic fibronectin peptides [112]. Mice overexpressing TGF $\beta 1$ in the secretory cells of both the mammary and salivary glands exhibit impaired salivary gland architecture concomitant with salivary gland hypofunction [113]. It is important to note that altered TGF $\beta 1$ expression in mice results in poor viability and surviving mice suffer from hyposalivation in association with inflammation, acinar cell atrophy and fibrosis in the salivary glands [111-113].

\section{Adaptor molecule Act-1-deficient mice}

As a negative regulator of BAFF and $\mathrm{CD} 40$, the adaptor molecule Act 1 (Act1) crucially modulates the survival of all B cells [114]. In Act1-deficient mice, similar to mice transgenic for BAFF, marginal-zone-like B cells dominate the inflammation in the exocrine gland that develops around 6 months of age [115]. At 8 months of age, levels of salivary secretion appear to be slightly diminished, while indications for dry eyes - such as scratching and skin lesions around the eyes - were observed during the breeding process as early as 3 weeks postpartum [115]. Another shared trait between the Act1-deficient strain and Baff transgenic mice is the production of SLEassociated anti-DNA autoantibodies and the manifestation of glomerulonephritis [115]. In contrast with Baff transgenic mice [106], however, deficiency in Act1 causes the production of autoantibodies specific for Ro and La [115]. Further investigation of this phenomenon revealed that, compared with the other autoantibody specificities found in these mice, the production of antiRo autoantibodies and anti-La autoantibodies critically depends on functional CD40. As Act1 was more recently also identified as a critical signaling component of the IL-17 signaling pathway, this aspect needs to be addressed in further studies [114].

\section{Thrombospondin-1-deficient mice}

A recent study showed that silencing the thrombospondin 1 gene (Thbs1) in C57BL/6 mice causes the development of a severe and remarkably complete SS-like disease with respect to the involvement of the eye [116]. Increased apoptosis in the lacrimal glands accompanies their progressive deterioration and, in addition, anti-Ro autoantibodies and anti-La autoantibodies were detected in this strain [116]. Some THBS1-deficient mice also displayed external signs of dry eyes, although the tear volume secreted upon stimulation did not differ between the genetically modified mice and the wild-type strain
[116]. Although a few parameters of lacrimal gland function significantly decreased before the significant influx of inflammatory cells into the glands, the authors argue for a critical involvement of the immune system, in particular the Th17 system, in the observed pathology [116].

THBS1 is capable of activating latent TGF $\beta$ and, as alluded to previously, dysregulation of the TGF $\beta$ system affects the immune system as well as multiple developmental processes. Although less devastating compared with direct deletion of $\operatorname{Tg} f \beta 1$, THBS1-deficient mice exhibit a similar inflammatory condition and display histological abnormalities described for TGF $\beta$-deficient mice [117]. Being a multidomain matrix glycoprotein capable of interacting with multiple cell adhesion molecules and proteases involved in angiogenesis, it is not surprising that THBS1 plays important roles in the development of diverse tissues [118]. Taking into account these properties of THBS1, investigating immune system-unrelated alterations in the exocrine tissues of Thbs1-deficient mice would further clarify the etiology of the disease they manifest.

\section{Aromatase-deficient mice}

The high female predominance and the late onset of SS in humans suggest a possible role of estrogen in the etiology of SS. Whereas neither estrogen receptor-alpha-deficient nor estrogen receptor-beta-deficient strains exhibit SS-like disease manifestations, another model for estrogen deficiency - the aromatase knockout mouse - develops a lymphoproliferative condition that in some aspects resembles the histopathological manifestation of SS in the salivary glands [119]. In parallel with sialoadenitis, B-celldominated inflammation of the kidneys and enlargement of the spleen were also reported for this strain [119].

\section{Retinoblastoma-associated protein $\mathbf{4 8}$ transgenic mice}

Estrogen deficiency caused by ovariectomy was shown to increase the number of epithelial cells undergoing apoptosis in the salivary glands as well as to have an effect on the cleavage of structural proteins [120]. The observation that retinoblastoma-associated protein 48 (RbAp48) contributes to the observed estrogen-dependent modulation of apoptosis exclusively in the salivary glands gave reason to investigate its role in a strain overexpressing $\mathrm{RbAp} 48$ under the control of a salivary gland specific promoter $[121,122]$. From 20 weeks of age onwards, RbAp48 transgenic mice exhibit inflammatory lesions in the salivary and lacrimal glands, which comprise mostly $\mathrm{T}$ cells and fewer B cells. At 30 weeks of age, salivary gland function was shown to be impaired in the transgenic mice compared with the wild-type strain. Increased levels of anti-Ro autoantibodies and anti-La autoantibodies complemented the SS-like phenotype observed in RbAp48 transgenic mice [122]. The investigators also 
collected considerable data that suggest a dominant role of resident cells in the initiation and perpetuation of the disease, especially by contributing to MHC-II-dependent antigen presentation and modulation of the cytokine milieu [122].

\section{Id3-deficient mice}

Inhibitors of DNA binding (ID) proteins are inhibitors of basic helix-loop-helix transcription factors and act as regulators of proliferation and differentiation of immune and non-immune cells [123]. The immune system of C57BL/6-Id3 ${ }^{-/-}$mice is characterized by alteration in humoral immune reactions, marginal zone B-cell development, B-cell precursor survival and both MHC-Irestricted and MHC-II-restricted positive and negative selection [124]. In these mice, T-cell-dominated focal inflammation develops between 6 and 12 months of age, coinciding with anti-Ro autoantibody and anti-La autoantibody production. The same strain, however, shows severe exocrine gland dysfunction as early as between 6 and 18 weeks of age - long before the appearance of focal lymphocytic foci in their exocrine glands [125]. Nevertheless, the notion that disruption of certain genes triggers distinct pathological changes, almost exclusively limited to the salivary and lacrimal glands, may encourage further investigation of possible interrelationships between organ and lymphocyte development and the etiology of autoimmune diseases. In this context, investigation of a T-cell-targeted conditional $I d 3$ knockout strain revealed the strong dependence of the original C57BL/6-Id3 ${ }^{-/-}$strain's disease profile on ID3-deficient $\mathrm{T}$ cells in particular [126]. Interestingly, depletion of $\mathrm{B}$ cells ameliorated the SS-like disease in this strain [127]. The role of ID3 in SS is now under investigation in humans, but to date there are no SNPs in $I d 3$ associated with SS in humans [128].

\section{Phosphoinositide 3 kinase class-IA-deficient mice}

There is an abundance of information that implicates phosphoinositide 3 kinase class IA in the development and onset of autoimmune diseases [129]. Mice with a Tcell-specific loss of phosphoinositide 3 kinase class IA $(\mathrm{r} 1 \Delta \mathrm{T} / \mathrm{r} 2 \mathrm{n})$ develop an inflammatory condition reminiscent of SS in the lacrimal glands that parallels the occurrence of inflammatory lesions in the lungs, liver and intestines in these mice [130]. While exocrine gland function was not assessed in detail, the authors report a decrease in $\mathrm{T}_{\text {regs }}$ in the periphery and increased anti-Ro antibodies and anti-La antibodies as a result of this specific genetic modification.

Knockin mice with mutated $\mathrm{\kappa B}$ enhancers in the $/ \kappa B a$ promoter Aberrant regulation of nuclear factor of kappa light polypeptide gene enhancer in B cells (NF-kB) has been associated with inflammatory and autoimmune diseases since its crucial role in both innate and adaptive immunity was reported [131]. Among other autoimmune conditions, certain polymorphisms in the promoter of NF- $\mathrm{kB}$ inhibitor nuclear factor of kappa light polypeptide gene enhancer in B-cells inhibitor alpha $(I \kappa B \alpha)$ might contribute to an individual's susceptibility to develop SS [132]. Removal of the feedback regulation of NF-кB by introducing $\kappa B$ enhancers in the $I_{\kappa} B \alpha\left(I_{\kappa} B \alpha^{M / M}\right)$ promoter of C57BL/6 mice altered the expression of NF-kBassociated genes such as $I l 17$ and genes involved in T-cell development [133]. Subsequently, inflammation in the exocrine glands, concomitant with production of anti-Ro autoantibodies, anti-La autoantibodies and anti-DNA autoantibodies, were observed in these mice without, however, assessing exocrine gland function [133]. The overall phenotype of this strain, in addition, is characterized by involvement of various other organs, shortened lifespan and hypersensitivity to septic shock [133].

\section{Extrinsic factor-induced models}

For the strains described earlier in this manuscript, the etiology of SS-like disease manifestations is assumed to be, to a large extent, associated with the mouse's specific genetic background. The experimental models presented below are strains in which the development of a SS-like pathology requires administration of extrinsic factors, such as proteins and peptides or viruses (Table 3). Such protocols are based on the concept that injecting specific components emulsified in an adjuvant can break immunological tolerance to certain organ-specific or organ-unspecific structures. This event might subsequently be followed by an immune-system-initiated pathogenesis. The components injected in such studies are mostly selected on the basis on their suspected role in the disease of interest. As alluded to previously, unfortunately, the current knowledge about disease-relevant autoantigens in SS is limited - which might be one reason why induced models are not of equal importance in SS as, for example, in studying multiple sclerosis [134] or rheumatoid arthritis [135].

\section{Ro peptides}

Repeated intraperitoneal injection of the Ro peptides Ro amino acids 480 to 494 or Ro amino acids 274 to 290 emulsified in complete Freund's adjuvant and later in Freund's incomplete adjuvant has been shown to recapitulate some manifestations of SS in Balb/c mice [136]. These mice present with hyposalivation, SS-like histopathology and production of anti-Ro antibodies and anti-La antibodies by 38 weeks of age [136]. Unfortunately, the actual penetrance rate of the SS-like disease proved to be low, thereby limiting the potential value of the model [136]. Oral feeding of Ro or Ro peptides 
abolished the susceptibility of Balb/c mice to SS-like disease induction through the experimental procedure described above [137]. While these studies were designed to determine whether Ro, as an autoantigen, is important in the etiology of SS, there is still a question as to how Ro might actually be presented to the immune system [138]. In light of a recent study indicating that Ro52 is a negative regulator of proinflammatory cytokine production [139], if and how these newly described properties of Ro52 contribute to SS remain to be investigated.

\section{Muscarinic acetylcholine type-3 receptor peptides}

As alluded to above, antibodies targeting the M3R may directly mediate the inhibition of exocrine gland secretion by inhibiting neuronal innervation of acinar cells. A recent study assessed the question further by vaccinating C57BL/6-M $3 r^{-1-}$ mice with a six-valent mixture of freeform extracellular peptides of M3R [140]. Indeed, the inoculation of splenocytes or $\mathrm{CD}^{+} \mathrm{T}$ cells into immunodeficient C57BL/6-Rag1 ${ }^{-/}$mice triggered the development of marked mononuclear cell inflammation in the exocrine glands accompanied by salivary gland hypofunction [140]. This study further supports the notion of a direct pathogenic role of anti-M3R immunity in SS [10].

\section{Carbonic anhydrase}

A subset of patients with autoimmune diseases, including patients with SS, produces autoantibodies against carbonic anhydrase II [141]. Studies carried out in mice revealed that experimental sialoadenitis can be induced through carbonic anhydrase II immunization of PL/J mice [142] as well as congenic strains of PL/J mice carrying the a $\mathrm{H} 2^{s}$ or a $\mathrm{H}^{u}$ haplotype [142]. Additional studies are required, however, to be able to estimate in more detail the resemblance of the disease manifested in this model with SS in humans.

\section{Murine cytomegalovirus}

Intraperitoneal injection of murine cytomegalovirus has been documented to lead to sialoadenitis and production of anti-Ro autoantibodies and anti-La autoantibodies in genetically modified C57BL/6 mice [143]. The modifications, affecting either FAS-mediated or TNFR1-mediated apoptosis, resulted in an incomplete clearance of murine cytomegalovirus, suggesting that any defect in this response may evoke chronic inflammation that resembles the histopathologlogical changes characteristic for SS [143]. In a subsequent study, C57BL/6-gld/gld mice, which are Fas ligand deficient, were treated with an adenoviral viral vector inducing the overexpression of Fas ligand [144]. In light of high levels of Fas ligand expression following injection of the vector, fewer than $5 \%$ of ductal and acinar cells proved to be apoptotic. Nevertheless, the intervention caused significant reductions in the number of inflammatory foci and the degree of tissue destruction in the salivary glands [144].

\section{Conclusions}

SS is a complex autoimmune exocrinopathy that over time often progresses to a systemic disease. Interpatient heterogeneity is a major component of this rheumatic disease, as evidenced by the array of symptoms exhibited by patients at clinic visits. Although numerous mouse strains are being proposed as models of SS, it is not surprising that no single model can perfectly match the full spectrum of SS observed in a human population. In the present review, we describe how the genetic background of these models and intervention protocols modulated the disease profile they project. Individual genetic alterations and their contribution to different disease stages and specific manifestations of SS might one day be assembled to depict a more complete and integrated picture of SS.

Today researchers are presented with several alternatives regarding spontaneous and genetically modified models of SS: yet, because of the complexity of SS, additional models will undoubtedly be required. Unfortunately, the limited knowledge about SS disease-relevant autoantigens and SS-related genetic risk factors continues to impede the development of extrinsic factorinduced models of SS.

In recent years there has been a positive trend towards testing hypotheses through genetic modification or intervention protocols in established models of SS. Results from these studies have often yielded insight into mechanisms potentially associated with the pathology of SS. The identification of B-cell-dependent mechanisms of pathogenesis in murine models, coupled with investigation of treatment strategies such as anti-CD20 antibodies targeting B cells in patients with SS, exemplify such translational advances. Nevertheless, it has become ever more challenging to keep pace with the developments in immunology and to be able to, at least partly, assess the importance of newly discovered components such as novel immune-cell subsets or regulatory pathways in a SS-related context. An assortment of wellcharacterized murine strains is needed in order to investigate possible roles of these components at the different stages of SS. In the past few years, there has also been an increase in the number of studies assessing the role of possibly relevant and immune system-unrelated processes in the etiology of SS. Again depending greatly on animal models, such research initiatives are expected to yield an increasing number of relevant biomarkers, which may specify an individual's risk of developing SS or may indicate an early stage of disease.

It also has become clear that murine strains, in some cases, represent a stereotypic or incomplete picture of 
their human disease counterpart. To counteract this issue, in-depth characterization of individual models as well as reliance on results obtained in multiple models is, however, anticipated to increase the success rate of translational studies.

In conclusion, many advances in the field of SS have their basis founded in discoveries initially made in animal models. Improved collaboration among scientists that develop animal models, researchers that apply animal models to investigate SS-related aims and clinicians that have access to well-defined SS patient cohorts should accelerate the discovery of novel disease mechanisms that lead to development of effective treatment regimens.

Autoimmune Basis of Rheumatic Diseases

This article is part of a series on Sjögren's syndrome, edited by Thomas Dörner, which can be found online at http://arthritis-research.com/ series/Sjögrens

This series forms part of a special collection of reviews covering major autoimmune rheumatic diseases, available at:

http://arthritis-research.com/series/abrd

\section{Abbreviations}

Act1, adaptor molecule Act 1; BAFF, B-cell-activating factor; dsRNA, doublestrand RNA; E2F1, E2F transcription factor 1; ID, inhibitors of DNA binding; IFN, interferon; $\mid \mathrm{KBa}$, nuclear factor of kappa light polypeptide gene enhancer in B-cells inhibitor alpha; IL, interleukin; M3R, muscarinic acetylcholine type-3 receptor; $\mathrm{MHC}$, major histocompatibility complex; NOD, nonobese diabetic mice; NF, nuclear factor; RbAp48, retinoblastoma-associated protein 48; SLE, systemic lupus erythematosus; SNP, single nucleotide polymorphism; SS, Sjögren's syndrome; STAT, signal transducer and activator of transcription; T1D, type 1 diabetes; TGF, transforming growth factor; Th, T-helper type; THBS1, thrombospondin $1 ; T N F$, tumor necrosis factor; $T_{\text {reg }}$, regulatory $T$ cell.

\section{Competing interests}

The authors declare that they have no competing interests.

\section{Acknowledgements}

The authors thank Dr B Delaleu-Justitz for careful revision of the manuscript. The authors received financial support from the following institutions: the Norwegian Research Council's GLOBVAC program (ND, RJ), the Strategic Research Program at Helse Bergen, Regional Health Authority for Western Norway (ND, RJ), the Broegelmann Foundation (ND, RJ) and PHS grants DE014344 (ABP), Al0819529 (ABP) and DE018958 (CQN) from the National Institutes of Health, USA.

\section{Author details}

'Broegelmann Research Laboratory, The Gade Institute, University of Bergen, New Laboratory Building, 5th floor, 5021 Bergen, Norway. ${ }^{2}$ Department of Oral Biology, College of Dentistry, University of Florida, Gainesville, 1600 SW Archer Road, FL 32610, USA. ${ }^{3}$ Department of Pathology, Immunology \& Laboratory Medicine, College of Medicine, University of Florida, 1600 SW Archer Road, Gainesville, FL 32610, USA. ${ }^{4}$ Center for Orphan Autoimmune Diseases, College of Dentistry, University of Florida, 1600 SW Archer Road, Gainesville, FL 32610, USA. ${ }^{5}$ Department of Rheumatology, Haukeland University Hospital, Jonas Liesvei 65, 5021 Bergen, Norway.

Published: 13 June 2011

\section{References}

1. Delaleu N, Jonsson R, Koller MM: Sjögren's syndrome. Eur J Oral Sci 2005, 113:101-113.
2. Jonsson R, Bowman SJ, Gordon TP: Sjögren's syndrome. In Arthritis and Allied Conditions. Edited by Koopman WJ. 15th edition. Philadelphia, PA: Lippincott Williams \& Wilkins; 2005:1681-1705.

3. Vitali C, Bombardieri S, Jonsson R, Moutsopoulos HM, Alexander EL, Carsons SE, Daniels TE, Fox PC, Fox RI, Kassan SS, Pillemer SR, Talal N, Weisman MH: Classification criteria for Sjögren's syndrome: a revised version of the European criteria proposed by the American-European Consensus Group. Ann Rheum Dis 2002, 61:554-558.

4. Theander E, Manthorpe R, Jacobsson LT: Mortality and causes of death in primary Sjögren's syndrome: a prospective cohort study. Arthritis Rheum 2004, 50:1262-1269.

5. Theander E, Henriksson G, Ljungberg O, Mandl T, Manthorpe R, Jacobsson LT: Lymphoma and other malignancies in primary Sjögren's syndrome: a cohort study on cancer incidence and lymphoma predictors. Ann Rheum Dis 2006, 65:796-803.

6. Hjelmervik TO, Petersen K, Jonassen I, Jonsson R, Bolstad Al: Gene expression profiling of minor salivary glands clearly distinguishes primary Sjögren's syndrome patients from healthy control subjects. Arthritis Rheum 2005, 52:1534-1544.

7. Båve U, Nordmark G, Lövgren T, Ronnelid J, Cajander S, Eloranta ML, Alm GV, Rönnblom L: Activation of the type I interferon system in primary Sjögren's syndrome: a possible etiopathogenic mechanism. Arthritis Rheum 2005, 52:1185-1195.

8. Ronnblom L, Alm GV, Eloranta ML: The type I interferon system in the development of lupus. Semin Immunol 2011, 23:113-121.

9. Garantziotis S, Hollingsworth JW, Zaas AK, Schwartz DA: The effect of toll-like receptors and toll-like receptor genetics in human disease. Annu Rev Med 2008, 59:343-359.

10. Dawson LJ, Fox PC, Smith PM: Sjögrens syndrome - the non-apoptotic model of glandular hypofunction. Rheumatology (Oxford) 2006, 45:792-798.

11. Delaleu N, Jonsson MV, Appel S, Jonsson R: New concepts in the pathogenesis of Sjögren's syndrome. Rheum Dis Clin North Am 2008, 34:833-845, vii.

12. Cha S, Peck AB, Humphreys-Beher MG: Progress in understanding autoimmune exocrinopathy using the non-obese diabetic mouse: an update. Crit Rev Oral Biol Med 2002, 13:5-16.

13. Jonsson MV, Delaleu N, Jonsson R: Animal models of Sjögren's syndrome. Clin Rev Allergy Immunol 2007, 32:215-224.

14. Mestas J, Hughes CC: Of mice and not men: differences between mouse and human immunology. J Immuno/ 2004, 172:2731-2738.

15. Brown SD, Wurst W, Kuhn R, Hancock JM: The functional annotation of mammalian genomes: the challenge of phenotyping. Annu Rev Genet 2009, 43:305-333.

16. Shaw DR: Searching the Mouse Genome Informatics (MGI) resources for information on mouse biology from genotype to phenotype. Curr Protoc Bioinformatics 2009, 25:17.11.11-17.11.14.

17. Shoda LK, Young DL, Ramanujan S, Whiting CC, Atkinson MA, Bluestone JA, Eisenbarth GS, Mathis D, Rossini AA, Campbell SE, Kahn R, Kreuwel HT: A comprehensive review of interventions in the NOD mouse and implications for translation. Immunity 2005, 23:115-126.

18. Keyes GG, Vickers RA, Kersey JH: Immunopathology of Sjögren-like disease in NZB/NZW mice. J Oral Pathol 1977, 6:288-295.

19. Jonsson R, Tarkowski A, Bäckman K, Klareskog L: Immunohistochemical characterization of sialadenitis in NZB X NZW F1 mice. Clin Immunol Immunopathol 1987, 42:93-101.

20. Kessler HS: A laboratory model for Sjögren's syndrome. Am J Pathol 1968, 52:671-685.

21. Kessler HS, Cubberly M, Manski W: Eye changes in autoimmune NZB and NZB x NZW mice. Comparison with Sjögren's syndrome. Arch Ophthalmol 1971, 85:211-219.

22. Deshmukh US, Ohyama Y, Bagavant H, Guo X, Gaskin F, Fu SM: Inflammatory stimuli accelerate Sjögren's syndrome-like disease in (NZB x NZW)F1 mice. Arthritis Rheum 2008, 58:1318-1323.

23. Hayashi T, Adachi C, Hasegawa K: Systemic treatment of anti-CD4CD25 T cell monoclonal antibody exacerbates sialoadenitis in submandibular glands during the early life in lupus-prone female NZB x NZWF mice. J Oral Pathol Med 2009, 38:234-240.

24. Deshmukh US, Nandula SR, Thimmalapura PR, Scindia YM, Bagavant H: Activation of innate immune responses through Toll-like receptor 3 causes a rapid loss of salivary gland function. $J$ Oral Pathol Med 2009, 38:42-47.

25. Hang L, Theofilopoulos AN, Dixon FJ: A spontaneous rheumatoid arthritis- 
like disease in MRL/I mice. J Exp Med 1982, 155:1690-1701.

26. Watanabe-Fukunaga R, Brannan Cl, Copeland NG, Jenkins NA, Nagata S: Lymphoproliferation disorder in mice explained by defects in Fas antigen that mediates apoptosis. Nature 1992, 356:314-317.

27. Singer $G G$, Abbas AK: The fas antigen is involved in peripheral but not thymic deletion of T lymphocytes in T cell receptor transgenic mice. Immunity 1994, 1:365-371.

28. Skarstein K, Nerland AH, Eidsheim M, Mountz JD, Jonsson R: Lymphoid cell accumulation in salivary glands of autoimmune MRL mice can be due to impaired apoptosis. Scand J Immunol 1997, 46:373-378.

29. Jonsson R, Tarkowski A, Backman K, Holmdahl R, Klareskog L: Sialadenitis in the MRL-I mouse: morphological and immunohistochemical characterization of resident and infiltrating cells. Immunology 1987, 60:611-616.

30. Jonsson R, Holmdahl R: Infiltrating mononuclear cells in salivary glands and kidneys in autoimmune MRL/Mp-lpr/lpr mice express IL-2 receptor and produce interferon-gamma. J Oral Pathol Med 1990, 19:330-334.

31. Skarstein $K$, Johannessen AC, Holmdahl R, Jonsson R: Effects of sialadenitis after cellular transfer in autoimmune MRL/lpr mice. Clin Immunol Immunopathol 1997, 84:177-184.

32. Jonsson R, Pitts A, Mestecky J, Koopman W: Local IgA and IgM rheumatoid factor production in autoimmune MRL/lpr mice. Autoimmunity 1991, 10:7-14.

33. Haneji $\mathrm{N}$, Hamano $\mathrm{H}$, Yanagi $\mathrm{K}$, Hayashi $Y$ : A new animal model for primary Sjögren's syndrome in NFS/sld mutant mice. J Immunol 1994, 153:2769-2777.

34. Haneji N, Nakamura T, Takio K, Yanagi K, Higashiyama H, Saito I, Noji S, Sugino $\mathrm{H}$, Hayashi Y: Identification of a-fodrin as a candidate autoantigen in primary Sjögren's syndrome. Science 1997, 276:604-607.

35. Zandbelt MM, Vogelzangs J, Van De Putte LB, Van Venrooij WJ, Van Den Hoogen FH: Anti-a-fodrin antibodies do not add much to the diagnosis of Sjögren's syndrome. Arthritis Res Ther 2004, 6:R33-R38.

36. Hayashi Y, Haneji N, Hamano H, Yanagi K, Takahashi M, Ishimaru N: Effector mechanism of experimental autoimmune sialadenitis in the mouse model for primary Sjögren's syndrome. Cell Immunol 1996, 171:217-225.

37. Saegusa J, Kubota H: Sialadenitis in IQI/Jic mice: a new animal model of Sjögren's syndrome. J Vet Med Sci 1997, 59:897-903.

38. Takada K, Takiguchi M, Konno A, Inaba M: Spontaneous development of multiple glandular and extraglandular lesions in aged IQI/Jic mice: a model for primary Sjögren's syndrome. Rheumatology (Oxford) 2004, 43:858-862

39. Takada K, Takiguchi M, Konno A, Inaba M: Autoimmunity against a tissue kallikrein in IQI/Jic Mice: a model for Sjögren's syndrome. J Biol Chem 2005, 280:3982-3988

40. Kaufman E, Lamster IB: The diagnostic applications of saliva - a review. Crit Rev Oral Biol Med 2002, 13:197-212.

41. Cha S, Nagashima H, Brown VB, Peck AB, Humphreys-Beher MG: Two NOD Idd-associated intervals contribute synergistically to the development of autoimmune exocrinopathy (Sjögren's syndrome) on a healthy murine background. Arthritis Rheum 2002, 46:1390-1398.

42. Robinson CP, Yamachika S, Bounous DI, Brayer J, Jonsson R, Holmdahl R, Peck $A B$, Humphreys-Beher MG: A novel NOD-derived murine model of primary Sjögren's syndrome. Arthritis Rheum 1998, 41:150-156.

43. Lindqvist AK, Nakken B, Sundler M, Kjellen P, Jonsson R, Holmdahl R, Skarstein $K$ : Influence on spontaneous tissue inflammation by the major histocompatibility complex region in the nonobese diabetic mouse. Scand $\mathrm{J}$ Immuno/ 2005, 61:119-127.

44. Anderson MS, Bluestone JA: The NOD mouse: a model of immune dysregulation. Annu Rev Immunol 2005, 23:447-485.

45. Setoguchi R, Hori S, Takahashi T, Sakaguchi S: Homeostatic maintenance of natural Foxp3(+) CD25(+) CD4(+) regulatory T cells by interleukin (IL)-2 and induction of autoimmune disease by IL-2 neutralization. J Exp Med 2005, 201:723-735.

46. Hawke CG, Painter DM, Kirwan PD, Van Driel RR, Baxter AG: Mycobacteria, an environmental enhancer of lupus nephritis in a mouse model of systemic lupus erythematosus. Immunology 2003, 108:70-78.

47. Quintana FJ, Pitashny M, Cohen IR: Experimental autoimmune myasthenia gravis in naive non-obese diabetic (NOD/LtJ) mice: susceptibility associated with natural $\lg G$ antibodies to the acetylcholine receptor. Int Immunol 2003, 15:11-16.

48. Gatumu MK, Skarstein K, Papandile A, Browning JL, Fava RA, Bolstad Al:
Blockade of lymphotoxin $\beta$ receptor signaling reduces aspects of Sjögren's syndrome in salivary glands of non-obese diabetic mice. Arthritis Res Ther 2009, 11:R24.

49. Wildenberg ME, Welzen-Coppens JM, van Helden-Meeuwsen CG, Bootsma H, Vissink A, van Rooijen N, van de Merwe JP, Drexhage HA, Versnel MA: Increased frequency of $\mathrm{CD} 6^{+}$monocytes and the presence of activated dendritic cells in salivary glands in primary Sjögren syndrome. Ann Rheum Dis 2009, 68:420-426.

50. Hunger RE, Carnaud C, Vogt I, Mueller C: Male gonadal environment paradoxically promotes dacryoadenitis in nonobese diabetic mice. J Clin Invest 1998, 101:1300-1309.

51. Delaleu N: The Autonomy of Different Aspects of Sjögren's Syndrome and their Treatment in an Experimental Model. Bergen: University of Bergen; 2008.

52. Jonsson MV, Delaleu N, Brokstad KA, Berggreen E, Skarstein K: Impaired salivary gland function in NOD mice: association with changes in cytokine profile but not with histopathologic changes in the salivary gland. Arthritis Rheum 2006, 54:2300-2305.

53. Nguyen CQ, Sharma A, She JX, McIndoe RA, Peck AB: Differential gene expressions in the lacrimal gland during development and onset of keratoconjunctivitis sicca in Sjögren's syndrome (SJS)-like disease of the C57BL/6.NOD-Aec1Aec2 mouse. Exp Eye Res 2009, 88:398-409.

54. Nguyen CQ, Sharma A, Lee BH, She JX, McIndoe RA, Peck AB: Differential gene expression in the salivary gland during development and onset of xerostomia in Sjögren's syndrome-like disease of the C57BL/6.NODAec1Aec2 mouse. Arthritis Res Ther 2009, 11:R56.

55. Burt RA, Watkins L, Tan IK, Wang N, Quirk F, Mackin L, Morgan P, Zhang JG, Berzins SP, Morahan G, Brodnicki TC: An NZW-derived interval on chromosome 7 moderates sialadenitis, but not insulitis in congenic nonobese diabetic mice. J /mmuno/ 2010, 184:859-868.

56. Delaleu N, Immervoll H, Cornelius J, Jonsson R: Biomarker profiles in serum and saliva of experimental Sjögren's syndrome: associations with specific autoimmune manifestations. Arthritis Res Ther 2008, 10:R22.

57. Delaleu N, Madureira AC, Immervoll H, Jonsson R: Inhibition of experimental Sjögren's syndrome through immunization with HSP60 and its peptide amino acids 437-460. Arthritis Rheum 2008, 58:2318-2328.

58. Salam MA, Matin K, Matsumoto N, Tsuha Y, Hanada N, Senpuku H: E2f1 mutation induces early onset of diabetes and Sjögren's syndrome in nonobese diabetic mice. J Immuno/ 2004, 173:4908-4918.

59. Matsui-Inohara H, Uematsu H, Narita T, Satoh K, Yonezawa H, Kuroda K, Ito T, Yoneda S, Kawarai T, Sugiya H, Watanabe H, Senpuku H: E2F-1-deficient NOD/SCID mice developed showing decreased saliva production. Exp Biol Med (Maywood) 2009, 234:1525-1536.

60. Kong L, Robinson CP, Peck AB, Vela-Roch N, Sakata KM, Dang H, Talal N, Humphreys-Beher MG: Inappropriate apoptosis of salivary and lacrimal gland epithelium of immunodeficient NOD-scid mice. Clin Exp Rheumatol 1998, 16:675-681.

61. Winer S, Astsaturov I, Cheung R, Tsui H, Song A, Gaedigk R, Winer D, Sampson A, McKerlie C, Bookman A, Dosch HM: Primary Sjögren's syndrome and deficiency of ICA69. Lancet 2002, 360:1063-1069.

62. Gordon TP, Cavill D, Neufing P, Zhang YJ, Pietropaolo M: ICA69 autoantibodies in primary Sjögren's syndrome. Lupus 2004, 13:483-484.

63. DeVoss JJ, LeClair NP, Hou Y, Grewal NK, Johannes KP, Lu W, Yang T, Meagher C, Fong L, Strauss EC, Anderson MS: An autoimmune response to odorant binding protein 1a is associated with dry eye in the Aire-deficient mouse. J Immunol 2010, 184:4236-4246

64. Robinson CP, Brayer J, Yamachika S, Esch TR, Peck AB, Stewart CA, Peen E, Jonsson R, Humphreys-Beher MG: Transfer of human serum IgG to nonobese diabetic $\lg \mu$ null mice reveals a role for autoantibodies in the loss of secretory function of exocrine tissues in Sjögren's syndrome. Proc Natl Acad Sci U S A 1998, 95:7538-7543.

65. Gao J, Killedar S, Cornelius JG, Nguyen C, Cha S, Peck AB: Sjögren's syndrome in the NOD mouse model is an interleukin-4 time-dependent, antibody isotype-specific autoimmune disease. J Autoimmun 2006, 26:90-103.

66. Nguyen CQ, Gao JH, Kim H, Saban DR, Cornelius JG, Peck AB: IL-4-STAT6 signal transduction-dependent induction of the clinical phase of Sjögren's syndrome-like disease of the nonobese diabetic mouse. J Immuno/ 2007, 179:382-390.

67. Soyfoo MS, De Vriese C, Debaix H, Martin-Martinez MD, Mathieu C, Devuyst O, Steinfeld SD, Delporte C: Modified aquaporin 5 expression and distribution in submandibular glands from NOD mice displaying autoimmune exocrinopathy. Arthritis Rheum 2007, 56:2566-2574. 
68. Ohashi Y, Tsuzaka K, Takeuchi T, Sasaki Y, Tsubota K: Altered distribution of aquaporin 5 and its C-terminal binding protein in the lacrimal glands of a mouse model for Sjögren's syndrome. Curr Eye Res 2008, 33:621-629.

69. Serreze DV, Chapman HD, Post CM, Johnson EA, Suarez-Pinzon WL, Rabinovitch A: Th1 to Th2 cytokine shifts in nonobese diabetic mice: sometimes an outcome, rather than the cause, of diabetes resistance elicited by immunostimulation. J Immuno/ 2001, 166:1352-1359.

70. Chatenoud L, Bach JF: Regulatory T cells in the control of autoimmune diabetes: the case of the NOD mouse. Int Rev Immunol 2005, 24:247-267.

71. Weaver CT, Hatton RD, Mangan PR, Harrington LE: IL-17 family cytokines and the expanding diversity of effector T cell lineages. Annu Rev Immuno/ 2007, 25:821-852.

72. Yanagi K, Ishimaru N, Haneji N, Saegusa K, Saito I, Hayashi Y: Anti-120-kDa a-fodrin immune response with Th1-cytokine profile in the NOD mouse model of Sjögren's syndrome. Eur J Immunol 1998, 28:3336-3345.

73. Yamano S, Atkinson JC, Baum BJ, Fox PC: Salivary gland cytokine expression in NOD and normal BALB/c mice. Clin Immunol 1999, 92:265-275.

74. Vosters JL, Yin H, Roescher N, Kok MR, Tak PP, Chiorini JA: Local expression of tumor necrosis factor-receptor 1:immunoglobulin $\mathrm{G}$ can induce salivary gland dysfunction in a murine model of Sjögren's syndrome. Arthritis Res Ther 2009, 11:R189.

75. Hunger RE, Muller S, Laissue JA, Hess MW, Carnaud C, Garcia I, Mueller C: Inhibition of submandibular and lacrimal gland infiltration in nonobese diabetic mice by transgenic expression of soluble TNF-receptor p55. J Clin Invest 1996, 98:954-961.

76. Mikulowska-Mennis A, Xu B, Berberian JM, Michie SA: Lymphocyte migration to inflamed lacrimal glands is mediated by vascular cell adhesion molecule-1/alpha(4)beta(1) integrin, peripheral node addressin/l-selectin, and lymphocyte function-associated antigen-1 adhesion pathways. Am J Pathol 2001, 159:671-681

77. Brayer JB, Cha S, Nagashima H, Yasunari U, Lindberg A, Diggs S, Martinez J, Goa J, Humphreys-Beher MG, Peck AB: IL-4-dependent effector phase in autoimmune exocrinopathy as defined by the NOD.IL-4-gene knockout mouse model of Sjögren's syndrome. Scand J Immunol 2001, 54:133-140.

78. Cha S, Brayer J, Gao J, Brown V, Killedar S, Yasunari U, Peck AB: A dual role for interferon-gamma in the pathogenesis of Sjögren's syndrome-like autoimmune exocrinopathy in the nonobese diabetic mouse. Scand J Immunol 2004, 60:552-565.

79. Nguyen $C Q, H u M H$, Li Y, Stewart C, Peck AB: Salivary gland tissue expression of interleukin-23 and interleukin-17 in Sjögren's syndrome: findings in humans and mice. Arthritis Rheum 2008, 58:734-743.

80. Nguyen $C Q$, Yin H, Lee BH, Carcamo WC, Chiorini JA, Peck AB: Pathogenic effect of interleukin-17A in induction of Sjögren's syndrome-like disease using adenovirus-mediated gene transfer. Arthritis Res Ther 2010, 12:R220.

81. Nguyen CQ, Yin H, Lee BH, Chiorini JA, Peck AB: IL17: potential therapeutic target in Sjögren's syndrome using adenovirus-mediated gene transfer. Lab Invest 2011, 91:54-62.

82. Hjelmervik TO, Lindqvist AK, Petersen K, Johannesson M, Stavrum AK, Johansson A, Jonsson R, Holmdahl R, Bolstad Al: The influence of the NOD Nss $1 /$ Idd5 loci on sialadenitis and gene expression in salivary glands of congenic mice. Arthritis Res Ther 2007, 9:R99.

83. Killedar SJ, Eckenrode SE, McIndoe RA, She JX, Nguyen CQ, Peck AB, Cha S: Early pathogenic events associated with Sjögren's syndrome (SjS)-like disease of the NOD mouse using microarray analysis. Lab Invest 2006 $86: 1243-1260$

84. Nguyen CQ, Cornelius JG, Cooper L, Neff J, Tao J, Lee BH, Peck AB: Identification of possible candidate genes regulating Sjögren's syndromeassociated autoimmunity: a potential role for TNFSF4 in autoimmune exocrinopathy. Arthritis Res Ther 2008, 10:R137.

85. Rozzo SJ, Vyse TJ, Menze K, Izui S, Kotzin BL: Enhanced susceptibility to lupus contributed from the nonautoimmune $\mathrm{C} 57 \mathrm{BL} / 10$, but not $\mathrm{C} 57 \mathrm{BL} / 6$, genome. J Immunol 2000, 164:5515-5521.

86. Hayashi Y, Utsuyama M, Kurashima C, Hirokawa K: Spontaneous development of organ-specific autoimmune lesions in aged C57BL/6 mice. Clin Exp Immuno/ 1989, 78:120-126.

87. Bulosan M, Pauley KM, Yo K, Chan EK, Katz J, Peck AB, Cha S: Inflammatory caspases are critical for enhanced cell death in the target tissue of Sjögren's syndrome before disease onset. Immunol Cell Biol 2009, 87:81-90.

88. Nguyen CQ, Kim H, Cornelius JG, Peck AB: Development of Sjögren's syndrome in nonobese diabetic-derived autoimmune-prone $\mathrm{C} 57 \mathrm{BL} / 6$. NOD-Aec1Aec2 mice is dependent on complement component-3.
J Immunol 2007, 179:2318-2329

89. Anderson JT, Cornelius JG, Jarpe AJ, Winter WE, Peck AB: Insulin-dependent diabetes in the NOD mouse model. II. Beta cell destruction in autoimmune diabetes is a TH2 and not a TH1 mediated event. Autoimmunity 1993 , 15:113-122.

90. Allison J, McClive P, Oxbrow L, Baxter A, Morahan G, Miller JF: Genetic requirements for acceleration of diabetes in non-obese diabetic mice expressing interleukin-2 in islet beta-cells. Eur J Immunol 1994, 24:2535-2541.

91. Sharma R, Zheng L, Guo X, Fu SM, Ju ST, Jarjour WN: Novel animal models for Sjögren's syndrome: expression and transfer of salivary gland dysfunction from regulatory T cell-deficient mice. J Autoimmun 2006, 27:289-296.

92. De Paiva CS, Hwang CS, Pitcher JD 3rd, Pangelinan SB, Rahimy E, Chen W, Yoon KC, Farley WJ, Niederkorn JY, Stern ME, Li DQ, Pflugfelder SC: Agerelated T-cell cytokine profile parallels corneal disease severity in Sjögren's syndrome-like keratoconjunctivitis sicca in CD25KO mice. Rheumatology (Oxford) 2010, 49:246-258.

93. Schimpl A, Berberich I, Kneitz B, Kramer S, Santner-Nanan B, Wagner S, Wolf M, Hunig T: IL-2 and autoimmune disease. Cytokine Growth Factor Rev 2002, 13:369-378.

94. Sharma R, Deshmukh US, Zheng L, Fu SM, Ju ST: X-linked Foxp3 (Scurfy) mutation dominantly inhibits submandibular gland development and inflammation respectively through adaptive and innate immune mechanisms. J Immuno/ 2009, 183:3212-3218.

95. Saito I, Haruta K, Shimuta M, Inoue H, Sakurai H, Yamada K, Ishimaru N, Higashiyama H, Sumida T, Ishida H, Suda T, Noda T, Hayashi Y, Tsubota K: Fas ligand-mediated exocrinopathy resembling Sjögren's syndrome in mice transgenic for IL-10. J Immunol 1999, 162:2488-2494.

96. Kok MR, Yamano S, Lodde BM, Wang J, Couwenhoven RI, Yakar S, Voutetakis A, Leroith D, Schmidt M, Afione S, Pillemer SR, Tsutsui MT, Tak PP, Chiorini JA, Baum BJ: Local adeno-associated virus-mediated interleukin 10 gene transfer has disease-modifying effects in a murine model of Sjögren's syndrome. Hum Gene Ther 2003, 14:1605-1618.

97. McGrath-Morrow S, Laube B, Tzou SC, Cho C, Cleary J, Kimura H, Rose NR, Caturegli P: IL-12 overexpression in mice as a model for Sjögren lung disease. Am J Physiol Lung Cell Mol Physiol 2006, 291:L837-L846.

98. Vosters JL, Landek-Salgado MA, Yin H, Swaim WD, Kimura H, Tak PP, Caturegli $P$, Chiorini JA: Interleukin-12 induces salivary gland dysfunction in transgenic mice, providing a new model of Sjögren's syndrome. Arthritis Rheum 2009, 60:3633-3641.

99. Tang JC, Ho FC, Chan AC, Srivastava G: Clonality of lymphomas at multiple sites in SJ mice. Lab Invest 1998, 78:205-212.

100. Kimura-Shimmyo A, Kashiwamura S, Ueda H, Ikeda T, Kanno S, Akira S, Nakanishi K, Mimura O, Okamura H: Cytokine-induced injury of the lacrimal and salivary glands. J Immunother 2002, 25(Suppl 1):S42-S51.

101. Shen L, Zhang C, Wang T, Brooks S, Ford RJ, Lin-Lee YC, Kasianowicz A, Kumar V, Martin L, Liang P, Cowell J, Ambrus JL Jr: Development of autoimmunity in IL-14alpha-transgenic mice. J Immuno/ 2006, 177:5676-5686.

102. Shen L, Suresh L, Li H, Zhang C, Kumar V, Pankewycz O, Ambrus JL, Jr: IL-14 alpha, the nexus for primary Sjögren's disease in mice and humans. Clin Immunol 2009, 130:304-312.

103. Gommerman JL, Browning JL: Lymphotoxin/light, lymphoid microenvironments and autoimmune disease. Nat Rev Immunol 2003, 3:642-655.

104. Shen L, Suresh L, Wu J, Xuan J, Li H, Zhang C, Pankewycz O, Ambrus JL, Jr: A role for lymphotoxin in primary Sjögren's disease. J Immunol 2010, 185:6355-6363.

105. Mackay F, Schneider P: Cracking the BAFF code. Nat Rev Immunol 2009, 9:491-502

106. Groom J, Kalled SL, Cutler AH, Olson C, Woodcock SA, Schneider P, Tschopp J, Cachero TG, Batten M, Wheway J, Mauri D, Cavill D, Gordon TP, Mackay CR, Mackay F: Association of BAFF/BLyS overexpression and altered B cell differentiation with Sjögren's syndrome. J Clin Invest 2002, 109:59-68.

107. Fletcher CA, Sutherland AP, Groom JR, Batten ML, Ng LG, Gommerman J, Mackay F: Development of nephritis but not sialadenitis in autoimmuneprone BAFF transgenic mice lacking marginal zone B cells. Eur J Immunol 2006, 36:2504-2514.

108. Gross JA, Johnston J, Mudri S, Enselman R, Dillon SR, Madden K, Xu W, ParrishNovak J, Foster D, Lofton-Day C, Moore M, Littau A, Grossman A, Haugen H, Foley K, Blumberg H, Harrison K, Kindsvogel W, Clegg CH: TACl and BCMA are receptors for a TNF homologue implicated in B-cell autoimmune disease. 
Nature 2000, 404:995-999.

109. Mackay F, Woodcock SA, Lawton P, Ambrose C, Baetscher M, Schneider P, Tschopp J, Browning JL: Mice transgenic for BAFF develop lymphocytic disorders along with autoimmune manifestations. J Exp Med 1999, 190:1697-1710

110. Batten M, Fletcher C, Ng LG, Groom J, Wheway J, Laabi Y, Xin X, Schneider P, Tschopp J, Mackay CR, Mackay F: TNF deficiency fails to protect BAFF transgenic mice against autoimmunity and reveals a predisposition to $B$ cell lymphoma. J Immuno/ 2004, 172:812-822.

111. Kulkarni AB, Huh CG, Becker D, Geiser A, Lyght M, Flanders KC, Roberts $A B$, Sporn MB, Ward JM, Karlsson S: Transforming growth factor beta 1 nul mutation in mice causes excessive inflammatory response and early death. Proc Natl Acad SciU S A 1993, 90:770-774

112. McCartney-Francis NL, Mizel DE, Redman RS, Frazier-Jessen M, Panek RB, Kulkarni AB, Ward JM, McCarthy JB, Wahl SM: Autoimmune Sjögren's-like lesions in salivary glands of TGF- $\beta 1$-deficient mice are inhibited by adhesion-blocking peptides. J Immuno/ 1996, 157:1306-1312.

113. Hall BE, Zheng C, Swaim WD, Cho A, Nagineni CN, Eckhaus MA, Flanders KC, Ambudkar IS, Baum BJ, Kulkarni AB: Conditional overexpression of TGF- $\beta 1$ disrupts mouse salivary gland development and function. Lab Invest 2010 90:543-555

114. Li X: Act1 modulates autoimmunity through its dual functions in CD40L/ BAFF and IL-17 signaling. Cytokine 2008, 41:105-113.

115. Qian Y, Giltiay N, Xiao J, Wang Y, Tian J, Han S, Scott M, Carter R, Jorgensen TN, Li X: Deficiency of Act1, a critical modulator of B cell function, leads to development of Sjögren's syndrome. Eur J Immunol 2008, 38:2219-2228.

116. Turpie B, Yoshimura T, Gulati A, Rios JD, Dartt DA, Masli S: Sjögren's syndrome-like ocular surface disease in thrombospondin-1 deficient mice. Am J Pathol 2009, 175:1136-1147.

117. Crawford SE, Stellmach V, Murphy-Ullrich JE, Ribeiro SM, Lawler J, Hynes RO, Boivin GP, Bouck N: Thrombospondin-1 is a major activator of TGF- $\beta 1$ in vivo. Cell 1998, 93:1159-1170.

118. Kazerounian S, Yee KO, Lawler J: Thrombospondins in cancer. Cell Mol Life Sci 2008, 65:700-712.

119. Shim GJ, Warner M, Kim HJ, Andersson S, Liu L, Ekman J, Imamov O, Jones ME, Simpson ER, Gustafsson JA: Aromatase-deficient mice spontaneously develop a lymphoproliferative autoimmune disease resembling Sjögren's syndrome. Proc Natl Acad Sci U S A 2004, 101:12628-12633.

120. Ishimaru N, Arakaki R, Watanabe M, Kobayashi M, Miyazaki K, Hayashi Y: Development of autoimmune exocrinopathy resembling Sjögren's syndrome in estrogen-deficient mice of healthy background. Am J Pathol 2003, 163:1481-1490.

121. Ishimaru N, Arakaki R, Omotehara F, Yamada K, Mishima K, Saito I, Hayashi Y: Novel role for RbAp48 in tissue-specific, estrogen deficiency-dependent apoptosis in the exocrine glands. Mol Cell Biol 2006, 26:2924-2935.

122. Ishimaru N, Arakaki R, Yoshida S, Yamada A, Noji S, Hayashi Y: Expression of the retinoblastoma protein RbAp48 in exocrine glands leads to Sjögren's syndrome-like autoimmune exocrinopathy. J Exp Med 2008, 205:2915-2927.

123. Yokota Y: Id and development. Oncogene 2001, 20:8290-8298.

124. Quong MW, Romanow WJ, Murre C: E protein function in lymphocyte development. Annu Rev Immunol 2002, 20:301-322.

125. Li H, Dai M, Zhuang Y: A T cell intrinsic role of Id 3 in a mouse model for primary Sjögren's syndrome. Immunity 2004, 21:551-560.

126. Guo Z, Li H, Han M, Xu T, Wu X, Zhuang Y: Modeling Sjögren's syndrome with Id3 conditional knockout mice. Immunol Lett 2011, 135:34-42.

127. Hayakawa I, Tedder TF, Zhuang Y: B-lymphocyte depletion ameliorates Sjögren's syndrome in Id3 knockout mice. Immunology 2007, 122:73-79.

128. Sellam J, Miceli-Richard C, Gottenberg JE, Proust A, Ittah M, Lavie F, Loiseau P, Mariette $X$ : Is Inhibitor of differentiation 3 involved in human primary Sjögren's syndrome? Rheumatology (Oxford) 2008, 47:437-441.
129. Fruman DA, Bismuth G: Fine tuning the immune response with PI3K. Immunol Rev 2009, 228:253-272.

130. Oak JS, Deane JA, Kharas MG, Luo J, Lane TE, Cantley LC, Fruman DA: Sjögren's syndrome-like disease in mice with $T$ cells lacking class $1 \mathrm{~A}$ phosphoinositide-3-kinase. Proc Natl Acad Sci U S A 2006, 103:16882-16887.

131. Vallabhapurapu S, Karin M: Regulation and function of NF-KB transcription factors in the immune system. Annu Rev Immunol 2009, 27:693-733.

132. Ou TT, Lin CH, Lin YC, Li RN, Tsai WC, Liu HW, Yen JH: IkBa promoter polymorphisms in patients with primary Sjögren's syndrome. J Clin Immunol 2008, 28:440-444.

133. Peng B, Ling J, Lee AJ, Wang Z, Chang Z, Jin W, Kang Y, Zhang R, Shim D, Wang $H$, Fleming JB, Zheng H, Sun SC, Chiao PJ: Defective feedback regulation of NF-KB underlies Sjögren's syndrome in mice with mutated kappaB enhancers of the IKBa promoter. Proc Natl Acad Sci U S A 2010, 107:15193-15198.

134. Mix E, Meyer-Rienecker $\mathrm{H}$, Zettl UK: Animal models of multiple sclerosis for the development and validation of novel therapies - potential and limitations. J Neuro/ 2008, 255(Suppl 6):7-14.

135. Hegen M, Keith JC, Jr, Collins M, Nickerson-Nutter CL: Utility of animal models for identification of potential therapeutics for rheumatoid arthritis. Ann Rheum Dis 2008, 67:1505-1515.

136. Scofield RH, Asfa S, Obeso D, Jonsson R, Kurien BT: Immunization with short peptides from the $60-\mathrm{kDa}$ Ro antigen recapitulates the serological and pathological findings as well as the salivary gland dysfunction of Sjögren's syndrome. J Immunol 2005, 175:8409-8414.

137. Kurien BT, Asfa S, Li C, Dorri Y, Jonsson R, Scofield RH: Induction of oral tolerance in experimental Sjögren's syndrome autoimmunity. Scand J Immunol 2005, 61:418-425.

138. Ohlsson M, Jonsson R, Brokstad KA: Subcellular redistribution and surface exposure of the Ro52, Ro60 and La48 autoantigens during apoptosis in human ductal epithelial cells: a possible mechanism in the pathogenesis of Sjögren's syndrome. Scand I Immunol 2002, 56:456-469.

139. Espinosa A, Dardalhon V, Brauner S, Ambrosi A, Higgs R, Quintana FJ, Sjostrand M, Eloranta ML, Ni Gabhann J, Winqvist O, Sundelin B, Jefferies CA, Rozell B, Kuchroo VK, Wahren-Herlenius M: Loss of the lupus autoantigen Ro52/Trim21 induces tissue inflammation and systemic autoimmunity by disregulating the IL-23-Th17 pathway. J Exp Med 2009, 206:1661-1671.

140. lizuka M, Wakamatsu E, Tsuboi H, Nakamura Y, Hayashi T, Matsui M, Goto D, Ito S, Matsumoto I, Sumida T: Pathogenic role of immune response to M3 muscarinic acetylcholine receptor in Sjögren's syndrome-like sialoadenitis. J Autoimmun 2010, 35:383-389.

141. Inagaki Y, Jinno-Yoshida Y, Hamasaki Y, Ueki H: A novel autoantibody reactive with carbonic anhydrase in sera from patients with systemic lupus erythematosus and Sjögren's syndrome. J Dermatol Sci 1991, 2:147-154.

142. Nishimori I, Bratanova T, Toshkov I, Caffrey T, Mogaki M, Shibata Y, Hollingsworth MA: Induction of experimental autoimmune sialoadenitis by immunization of PL/J mice with carbonic anhydrase II. J Immunol 1995, 154:4865-4873.

143. Fleck M, Kern ER, Zhou T, Lang B, Mountz JD: Murine cytomegalovirus induces a Sjögren's syndrome-like disease in C57BI/6-lpr/lpr mice. Arthritis Rheum 1998, 41:2175-2184.

144. Fleck M, Zhang HG, Kern ER, Hsu HC, Muller-Ladner U, Mountz JD: Treatment of chronic sialadenitis in a murine model of Sjögren's syndrome by local fasL gene transfer. Arthritis Rheum 2001, 44:964-973.

doi:10.1186/ar3313

Cite this article as: Delaleu N, et al.: Sjögren's syndrome: studying the

disease in mice. Arthritis Research \& Therapy 2011, 13:217. 